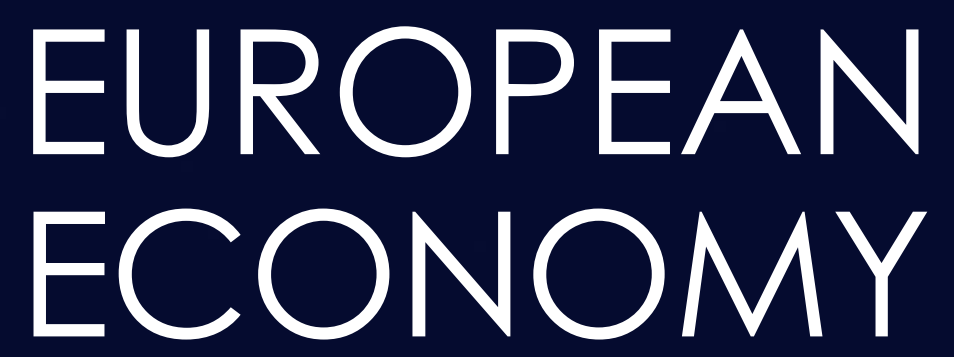

Economic Papers 356 | January 2009

\title{
International Taxation and Multinational Firm Location Decisions
}

Salvador Barrios, Harry Huizinga , Luc Laeven and Gaëtan Nicodème 
Economic Papers are written by the Staff of the Directorate-General for Economic and Financial Affairs, or by experts working in association with them. The Papers are intended to increase awareness of the technical work being done by staff and to seek comments and suggestions for further analysis. The views expressed are the author's alone and do not necessarily correspond to those of the European Commission. Comments and enquiries should be addressed to:

European Commission

Directorate-General for Economic and Financial Affairs

Publications

B-1049 Brussels

Belgium

E-mail: Ecfin-Info@ec.europa.eu

This paper exists in English only and can be downloaded from the website http://ec.europa.eu/economy finance/publications

A great deal of additional information is available on the Internet. It can be accessed through the Europa server (http://europa.eu )

KC-AI-09-356-EN-N

ISBN 978-92-79-08379-2

ISSN $1725-3187$

DOI $10.2765 / 11668$

(C) European Communities, 2009 


\title{
International Taxation and Multinational Firm Location Decisions
}

\author{
Salvador Barrios \\ (European Commission) \\ Harry Huizinga* \\ (Tilburg University and CEPR) \\ Luc Laeven \\ (International Monetary Fund and CEPR) \\ and \\ Gaëtan Nicodème \\ (European Commission, CEB, CESifo and ECARES)
}

\begin{abstract}
Using a large international firm-level data set, we estimate separate effects of host and parent country taxation on the location decisions of multinational firms. Both types of taxation are estimated to have a negative impact on the location of new foreign subsidiaries. In fact, the impact of parent country taxation is estimated to be relatively large, possibly reflecting its international discriminatory nature. For the cross-section of multinational firms, we find that parent firms tend to be located in countries with a relatively low taxation of foreign-source income. Overall, our results show that parent-country taxation - despite the general possibility of deferral of taxation until income repatriation - is instrumental in shaping the structure of multinational enterprise.
\end{abstract}

Key words: corporate taxation, dividend withholding taxation, location decisions JEL classifications: F23, G32, H25, R38

\footnotetext{
* Corresponding author. Department of Economics, Tilburg University, 5000 LE Tilburg, Netherlands, Tel. +31-13-4662623, E-mail: huizinga@uvt.nl. The authors thank the participants at the ECFIN internal seminar at the European Commission for valuable comments. The findings, interpretations, and conclusions expressed in this paper are entirely those of the authors. They should not be attributed to the European Commission or the International Monetary Fund.
} 


\section{Introduction}

With globalization and the progressive removal of barriers to trade, an increasing number of companies develop international activities. To access foreign markets, firms face a choice between producing goods at home for exports and producing abroad. A host of tax and non-tax factors affect the decision whether to relocate production abroad. Among the non-tax factors are the size of a foreign market, its growth prospects, wage and productivity levels abroad, the foreign regulatory and legal environment, and distance from the home country (see Görg and Greenway (2004), Barrios et al. (2005) and Mayer and Ottaviano (2007) for recent reviews). The impact of taxation on foreign direct investment (FDI) has been the subject of a sizeable literature, as reviewed by de Mooij and Everdeen (2006) and Devereux and Maffini (2007).

Studies of the effect of taxation on FDI location decisions generally examine host country taxation to the exclusion of parent country taxation. The contribution of this paper is to jointly consider the impact of host and parent country taxation on multinational firm location decisions. As a first level of taxation, the host country may impose corporate income taxation on the income of local foreign subsidiaries. In addition, the host country could levy a non-resident dividend withholding tax on the subsidiary's earnings at the time they are repatriated to the parent firm. But taxation need not stop at the host country level. The parent country can further choose to levy a corporate income tax on the resident multinational's foreign-source income. We examine the independent impact of all three levels of taxation on the location decisions of European multinationals over the period 1999-2003.

A multinational consists of a parent firm in one country and foreign subsidiaries in one or more foreign countries. In this paper we consider the impact of international taxation on the firm's location choices regarding the parent firm as well as any foreign subsidiary. First, we reconsider the traditional problem of choosing the location of FDI. Specifically, we 
examine how multinationals headquartered in a certain country choose the location of new foreign subsidiaries. Second, we contribute to the literature on the organizational structure of the multinational firm by examining the location choice of the parent firm. A multinational firm with a parent firm in a particular country can develop in a variety of ways, including the establishment of new foreign subsidiaries, cross-border M\&As, and the inversion of preexisting multinational firms whereby a previous foreign subsidiary becomes the new parent firm. Rather than consider these mechanisms separately, our approach in this paper is to examine the existing distribution of multinationals at a particular point in time to see whether there is a tendency for the parent firm to be located in the county that levies a relatively low international taxation of foreign-source income.

For this study, we have collected detailed information on how parent-country tax systems interact bilaterally with corporate taxation and non-resident withholding taxation in the host country. Specifically, we collect information on whether or not countries tax the income of their multinationals on a worldwide basis, and whether foreign tax credits are provided for non-resident withholding taxes only or also for the underlying host country corporate tax (as, for instance, in the United States). As an alternative to worldwide taxes, parent countries may partially or fully exempt foreign source income from taxation. As an example, Germany exempts 95 percent of the foreign source income of German multinationals from taxation.

Data on the international structures of European multinationals are obtained from the Amadeus database. This data set allows us to consider multinational companies resident in a broad set of countries, each potentially having foreign subsidiaries in many other countries. Thus, unlike earlier work, this paper considers multinational firm location choices in a setting of $\mathrm{N}$ by $\mathrm{N}$ countries. In addition to being an innovative approach, this multi-country framework is in fact necessary to obtain sufficient variation in parent-country corporate 
taxation (not highly correlated with host-country corporate taxation) to be able to separately estimate its impact on international location decisions.

Host-country and parent-country corporate income taxation both appear to discourage the location of foreign subsidiaries in a particular country. In fact, the estimated negative impact of the two types of taxation - as derived from statutory tax information - is about of equal size. At first glance, this result is surprising as the option to defer parent-country corporate taxation would suggest that this type of taxation is relatively unimportant. After all, this has often been the argument for not including parent-country corporate tax rates in studies of location choices in the first place. The sizeable impact of parent-country taxation on location choices could reflect that this type of taxation tends to be discriminatory against foreign ownership by a particular country. International parent-country taxation obviously does not apply to local owners of productive assets, and it may also not apply or apply less to potential foreign owners from third countries. Parent country taxation thus tends to put foreign owners from a particular country at a competitive disadvantage, which can explain a greater incentive to avoid this type of taxation.

A multinational that chooses its parent-firm location from among the countries where it operates will have to pay the same corporate income taxes applied to locally generated income regardless of the location of its headquarters. The only differences in fact lie in potentially different non-resident dividend withholding taxes and parent-country corporate income taxes. Thus, naturally we only expect variation in these international taxation across potential parent countries to affect headquarter location. Our results suggest that the corporate taxation of foreign-source income is important in shaping the organizational structure of multinational firms.

Some firms are interested in becoming international by establishing only a single foreign subsidiary somewhere, while others have a need to maintain subsidiaries in almost 
every corner of the world. At the same time, some multinationals may consider the entire world as a potential choice of location, while others - for whatever reason - can only effectively operate in a limited number of countries. These subsidiary and country 'dimensions' of a multinational's location choices can be expected to affect the sensitivity of location to international taxation. To see this, note that the probability of subsidiary location in any one of many countries is rather small, if a multinational wishes to establish a foreign subsidiary in only one country. Correspondingly, we expect that the impact of taxation on the probability of location in a country to be rather small as well. For a multinational that wishes to operate in 2 or more countries (out of many), the sensitivity of the probability of location to taxation may be higher. Along similar lines, the sensitivity of the likelihood of location to taxation may be relatively high, if a multinational has to pick a single country of location out of 2 countries rather than out of many.

The multi-country nature of our data set allows us to investigate how these dimensions of a multinational's choice problem affect estimated tax sensitivities. We indeed find that the tax sensitivity of location increase with the number or countries of location (for low numbers of location countries), and in fact peaks for intermediate numbers of countries of location. As a methodological exercise, we further estimate the tax sensitivity of location choice regarding foreign subsidiaries for multinationals headquartered in one of three countries (France, Germany, or the United Kingdom) that establish foreign subsidiaries in one or more of these countries. When we somewhat arbitrarily shrink the choice set in this way, we indeed estimate a rather sizeable tax coefficient. These results together suggest that estimates of tax sensitivities of location decisions are best based on large international data sets as in the current paper, and that firm heterogeneity regarding the scale of needed foreign establishments matters. 
Devereux and Griffith (1998) investigate how host-country taxation affects the subsidiary location decisions of US multinationals in several large European countries (France, Germany, and United Kingdom) over the period 1980-1994. They find that conditional on the choice to locate production abroad - host-country average effective tax rates (but not marginal effective tax rates) are important in determining foreign location choice, even if taxation does not appear to affect the earlier choice to locate abroad or to export. For German multinationals, Buettner and Ruf (2007) in turn find that location decisions in 18 potential host countries between 1996 and 2003 are affected more by hostcountry statutory tax rates than effective average tax rates, while they find no effect of marginal effective tax rates.

Several authors have previously found a role for parent-country taxation to affect the location of FDI. For US multinationals, Kemsley (1998) finds that the host country tax only affects the ratio of US exports to foreign production over the period 1984-1992 if the multinationals find themselves in excess credit positions. ${ }^{1}$ Analogously, a role of parentcountry taxation in affecting FDI into the United States is found by Hines (1996), who shows that foreign countries with worldwide taxation invest relatively much in US states with high state taxes. This reflects that multinationals located in countries with worldwide taxation may be able to obtain foreign tax credits for US state corporate income taxes.

In the remainder, section 2 describes the tax treatment of the foreign-source income of multinational firms. Section 3 discusses our firm-level data. Section 4 presents estimates of the impact of international taxation on the location of foreign subsidiaries. Section 5 in turn

\footnotetext{
${ }^{1}$ US multinationals are subject to worldwide taxation in the United States. Thus, they have to pay tax in the United States on their foreign-source income, subject to the provision of a foreign tax credit for taxes already paid in the host country. The foreign tax credit, in practice, is limited to the amount of US tax due on the foreign-source income. This implies that the overall tax on the foreign income is the host country tax if this tax exceeds the US tax, while it is the US tax if this tax is the higher of the two. US taxes on foreign source income can be deferred until the income is repatriated.
} 
provides evidence on the impact of international taxation on parent firm location. Finally, section 6 concludes.

\section{The international tax system}

This section describes the corporate tax system applicable to a multinational company with foreign subsidiaries. ${ }^{2}$ Consider a multinational company with a parent located in home country $p$ and a subsidiary located in host country $s$. Both home and host countries may tax the subsidiary's income. First, the host country may levy a corporate income tax at rate $t_{s}$ on this income. The second column of Table 1 shows the statutory corporate income tax rates for the 33 European countries in our sample for the year $2003 .^{3}$ These statutory tax rates are those on distributed profits and include local taxes and applicable surcharges. In our sample, the corporate tax rates for 2003 range from a low of $12.5 \%$ in Ireland to a high of $39.59 \%$ in Germany.

Next, the host country levies a non-resident dividend withholding tax at rate $w_{s}$ on the subsidiary's net-of-corporate-tax income upon repatriation of this income to the parent. Table 2 provides information on the applicable withholding tax rates on dividends paid by fullyowned subsidiaries to their non-resident parents in 2003. For example, a dividend paid by a Belgian subsidiary to its parent company located in Estonia will bear a withholding tax of $25 \%$, while the withholding tax on a dividend paid by an Estonian subsidiary to its Belgian parent company has a zero rate. The withholding tax rates for transactions involving two EU Member States are zero on account of the EU Parent-Subsidiary Directive ${ }^{4}$.

\footnotetext{
${ }^{2}$ See also Huizinga, Laeven and Nicodème (2008) for a description of corporate tax systems as they apply to multinational companies.

${ }^{3}$ For illustrative purposes, the tables report taxation data for the year 2003 only, although we have collected these data for the entire period 1999-2003.

${ }^{4}$ Note that in 2003, prior to their adhesion, many new EU Member States still maintained non-zero rates vis-àvis EU countries and vice versa.
} 
The net-of-withholding-tax dividend by the parent company is in principle taxed in the parent country - subject to some form of double tax relief as recommended by the OECD Model Tax Treaty or as prescribed in the EU Parent-Subsidiary Directive. Some countries operate an exemption system. In this instance, the dividend is not taxed in the parent country, if the provided exemption is full. The overall international rate of taxation on the subsidiary's income is then given by $1-\left(1-t_{s}\right)\left(1-w_{s}\right)$ or $t_{s}+w_{s}-t_{s} w_{s}$.

Alternatively, the home country may tax the worldwide income of its multinationals and subject the received dividend to corporate income taxation at a rate $t_{p}$. Generally, a foreign tax credit is provided for taxes paid in the host country, usually limited to the amount of the home tax due on the foreign-source income. Some countries apply an indirect tax credit system under which both the corporate tax and the withholding tax paid in the host country are credited against the home corporate income tax. In case the home country's corporate income tax $t_{p}$ is higher than the overall host country tax rate $t_{s}+w_{s}-t_{s} w_{s}$, the firm pay income tax in the home country at a rate $t_{p}-\left[t_{s}+w_{s}-t_{s} w_{s}\right]$ so that combined, effective tax rate is equal to $t_{p}$. If instead the home country's corporate income tax rate is lower than the overall host country's rates, the firm is said to be in excess foreign tax credit and it will pay no further tax in the home country (having reduced its home tax liability to zero by using foreign tax credits). In this instance, the combined, effective tax rate is $t_{s}+w_{s}-t_{s} w_{s}$. In summary, for home countries with an indirect tax credit system, the combined, effective tax rate is equal to $\max \left[t_{p} ; t_{s}+w_{s}-t_{s} w_{s}\right]$

Home countries may restrict the foreign tax credit to cover only host country nonresident withholding taxes giving rise as under a direct tax credit system. In this case, the multinational has to pay tax in the parent country to the extent that $t_{p}$ exceeds $w_{s}$ and now that combined, effective tax rate is given by $t_{s}+\left(1-t_{s}\right) \max \left[t_{p}, w_{s}\right]$. 
Alternatively, some home countries offer neither exemption nor a foreign tax credit for taxes paid abroad, but instead allow foreign taxes to be deducted from home-country taxable corporate income. This amounts to the deduction system with a combined, effective tax rate of $1-\left(1-t_{s}\right)\left(1-w_{s}\right)\left(1-t_{p}\right)$

Finally, in some rather exceptional cases, no double tax relief is provided at all. With full double taxation, the combined, effective tax rate becomes $t_{s}+w_{s}-t_{s} w_{s}+t_{p}$.

Columns 3 and 4 of table 1 indicate which double tax relief system is applied by European countries. As seen in the table, some countries provide different double tax relief to treaty partners and non-treaty countries. Thus, we need to know whether there exist double tax treaties among the countries in our sample. On a bilateral basis, this information is provided in table 3 with the value 1 indicating the existence of such a treaty and 0 otherwise. The table indicates that for many countries the treaty network is not complete. For example, in 2003 Czech Republic has a treaty with all countries in the sample except Malta and Turkey. From Table 1, we see that this implies that dividends from all foreign subsidiaries paid to a Czech parent benefit from an indirect tax credit, except for those paid by a Maltese or a Turkish subsidiary where the deduction system applies. Information from Tables 1 to 3 allows us to calculate the combined, effective tax rate on foreign dividend for any pair of home and host countries. To fix ideas, consider the case of a dividend paid by a Maltese subsidiary to its Czech parent in 2003. Table 1 shows that the statutory corporate tax rate in Malta is $35 \%$. We infer from Table 2 that net profits paid as a dividend to a foreign company are never subject to a non-resident dividend withholding tax in Malta. As already mentioned, Table 3 indicates that no tax treaty was in force between the two countries in 2003 so that from Table 1 we see that incoming foreign dividends benefit from a deduction system in Czech Republic. Finally, the same table indicates that the applicable corporate tax rate in this country is $31 \%$. From the formula above, the combined, effective tax rate equals $1-(1-$ 
$0.35) \times(1-0) \times(1-0.31)=55.15 \%$. This rate is considerably higher than the Maltese corporate tax rate of $35 \%$. This suggests that the additional taxation of multinational firms, in the form of withholding taxes and home country corporate income taxation, potentially has an independent and significant impact on international location decisions.

Below, we will investigate the independent influences of host-country corporate income and dividend withholding taxation and home-country corporate income taxation on corporate location decisions. To make parameter estimates comparable across tax measures, it is useful to construct all three tax measures as shares of the foreign subsidiary's pre-tax income. The host country tax rate, of course, is already defined as a share of the subsidiary's pre-tax income. Our withholding tax measure will be $\left(1-t_{s}\right) w_{\mathrm{s}}$ to reflect that the withholding tax applies to the subsidiary's income net of the host country corporate tax. Finally, the residual parent country corporate income tax - as a share of the subsidiary's pre-tax income is computed as the difference between the combined, effective tax rate and $t_{s}+w_{s}-t_{s} w_{s} \mathrm{We}$ will define the international tax to be the sum of the withholding tax and residual parentcountry corporate tax both expressed as shares of the subsidiary's pre-tax income. Equivalently, the international tax is the difference between the combined, effective tax and the host country corporate income tax.

Unlike host-country corporate income taxes, withholding taxes and home-country corporate income taxes are generally deferred until the foreign source income is repatriated to the parent in the form of dividends. Deferral, of course, reduces the present value of taxation. Thus, withholding taxes and home-country corporate income taxes - all calculated as shares of the subsidiary's pre-tax income - are expected to 'bite' less than host country corporate income taxes. Whether the deferral of withholding taxes and home-country corporate income taxes serves to make these taxes immaterial for location decisions is an empirical matter. This is what we turn to in the empirical section below. 


\section{Multinational enterprise data}

The data on the structure of multinational firms in Europe are taken from the Amadeus database. ${ }^{5}$ This database provides standard accounting data as well as data on ownership relationships within corporate groups. The ownership data enable us to match European firms with their domestic subsidiaries and foreign subsidiaries located in other European countries. ${ }^{6}$ A firm is taken to be a subsidiary, if at least $50 \%$ of the shares are owned by a single other firm. A multinational company has one or more foreign subsidiaries. We have data on multinational firms operating in 33 European countries over the years 19992003.

Information on the number of parent companies and subsidiaries in our data set is provided in Panel A of Table 4. The total number of parent companies is 906, while the number of foreign subsidiaries is 3,094. The United Kingdom with 144 parent companies has most parent companies, followed by France with 116 parent companies. Each subsidiary has a home country (where its parent is located) and a host country (where it is located itself). For each country, the table lists the number of subsidiaries by home country and by host country. The table indicates that, for example, France, Spain and the United Kingdom are the home country to relatively many subsidiaries. Hence, there are relatively many subsidiaries with a parent firm in one of these countries. Denmark, Spain and the United Kingdom, instead, are the host country to relatively many subsidiaries.

\footnotetext{
${ }^{5}$ The database is created by collecting standardized data received from 50 vendors across Europe. The local source for this data is generally the office of the Registrar of Companies.

${ }^{6}$ The Amadeus database only contains information on European firms and we therefore only cover the European operations of the multinationals in our sample. Therefore, we cannot consider how tax differences between European countries and other parts of the world affect the capital structure of subsidiaries in Europe. While this is an important caveat to be mentioned, we do not see this as a major limitation of our analysis because European multinationals typically derive much of their revenues from operations in Europe rather than other parts of the world.
} 
Our subsequent empirical work on foreign subsidiary location aims to predict the location of a new foreign subsidiary in one of 32 foreign European countries. The dependent variable, called Subsidiary location, takes on a value of one if a particular country is selected as a subsidiary's location and it is zero otherwise.

Summary statistics on the subsidiary location variable, the tax variables and some controls are provided in Panel B of Table 4 (see the Appendix for variable definitions and data sources). The 26,567 observations reported in the table reflect the basic regression 1 of Table $5 .^{7}$ The mean value of the overall effective tax is 0.353 . This mean effective tax, in effect, is the sum of a mean host country tax of 0.302 and a mean international tax of 0.051 .

Among the control variables, GDP bilateral is the ratio of the GDP of a potential host country and the sum of the GDPs of all other potential foreign (but not domestic) locations. This variable captures market size, and it is expected to exert a positive impact on the probability of subsidiary location in a host country.

Next, Contiguity is a dummy variable signaling a common border between host and home countries. A common border is expected to make location in the host country more likely.

Origin of Law is a dummy variable indicating whether host and home countries both have legal systems with a common origin. Similar legal systems may promote subsidiary location if it facilitates international legal work. On the other hand, legal system similarity may discourage location, if multinationals subject to a superior legal system can benefit from 'exporting' this system to countries with inferior systems.

Difference in labor costs is the log of the absolute value of the difference in labor costs between host and home countries in a common currency. High host-country labor costs are expected to discourage subsidiary location. 
Economic freedom is an index of the extent of soundness of the legal system, absence of trade barriers and absence of price controls. Economic freedom should make a country attractive as a subsidiary location.

Finally, EU membership subsidiary is a dummy variable flagging EU membership of a prospective host country. EU membership, to the extent that is signals commitment to EU standards of dealing with foreign investors, could engender subsidiary location.

Panel $\mathrm{C}$ of Table 4 provides correlation coefficients among the location, tax and control variables. Interestingly, location is positively and significantly related to the host country tax, but negatively and significantly to the international tax. The first correlation reflects that subsidiaries tend to be located in larger countries, which tend to have relatively high corporate income taxes. In the table, the host country tax is indeed positively and significantly correlated with the GDP bilateral variable as an index of host country relative size. The negative correlation between location and the international tax could reflect that subsidiary location is chosen so as to mitigate international double taxation. Also note that the host country tax and the international tax are negatively correlated, perhaps reflecting the operation of the foreign tax credit mechanism.

\section{Empirical results on taxation and subsidiary location}

\subsection{Basic results}

One important way to change the structure of multinational firms is to establish a new foreign subsidiary (either by starting the foreign establishment from scratch or by acquiring it). Initially, we examine the location of new foreign subsidiaries, i.e. the location of foreign subsidiaries only during the first year that they report accounting data. Specifically, we consider foreign subsidiaries that appear first in one of the years 1999 to 2003. By only

\footnotetext{
${ }^{7}$ Note that the mean value of the location variable is not exactly $1 / 32$ due to the absence of data for some
} 
considering location choice in the year of establishment, we ensure that observations for different foreign subsidiaries are independent. By focusing on only foreign subsidiaries, we condition on a foreign location and hence examine the impact of international taxation on the location choice among competing foreign locations. Our data set encompasses 33 European countries, which implies that for a multinational resident in a particular country there are 32 foreign location options. Accordingly, for each new foreign subsidiary, we construct 32 binary variables that take on a value of one if location is in a certain foreign country and zero otherwise. Regarding each potential location for each new foreign subsidiary, there thus is a binary choice. Location choice is assumed to be determined by the international tax system and a range of other location or country characteristics. The underlying binary choice model is estimated using the conditional logit approach of McFadden $(1974,1976){ }^{8}$

Regression 1 in Table 5 includes the effective tax rate, i.e. the sum of the host-country corporate income tax rate and the international tax rate, yielding a coefficient of -3.964 that is significant at the 1 percent level. Alternatively, a one percentage point increase in the effective tax rate is estimated to reduce the probability of location in a country by 0.615 percent, while the semi-elasticity of the probability of location with respect to the effective tax rate is estimated to be -0.761 . Among the controls, a country's relative GDP is estimated to increase the probability of subsidiary location. Contiguous countries similarly are more likely to receive foreign subsidiaries. Similarity of legal systems, as proxied by the Origin of Law variable, instead appears to discourage location. This could reflect that multinationals subject to, say, a common law system aim to 'export' some of the benefits of such a legal system to countries with other legal systems. Relatively high labor costs in a prospective host country in addition appear to make prospective host countries less attractive. Economic

\footnotetext{
location options.

${ }^{8}$ The conditional logit model imposes the axiom of independence of irrelevant alternatives, which implies that adding a third option or changing the characteristics of a third alternative does not affect the relative odds between any two options considered.
} 
liberalization, as proxied by the Economic Freedom variable, instead makes potential host countries more attractive. EU membership, finally, is seen to have a positive impact on the probability of foreign subsidiary location.

Regression 2 substitutes the host country corporate tax rate for the effective tax rate. The estimated parameter on the host country tax variable has a somewhat smaller magnitude of -2.929 and it is again significant at the 1 percent level. In line with this, a one percentage point increase in the host country tax rate is estimated to reduce the probability of location by 0.274 percent, while the estimated semi-elasticity of the probability of location with respect to the host country tax rate is -0.306 . The controls enter regression 2 in qualitatively the same way as before.

Regression 3 in turn includes the international tax variable - reflecting both nonresident withholding taxation in the host country and parent country corporate taxation with an estimated coefficient of -2.205 . The corresponding marginal effect and semielasticity of the probability of location with respect to the international tax rate are estimated to be relatively large at -0.074 and -0.076 , but these estimates are statistically insignificant.

Next, regression 4 includes the host country tax rate and the international tax rate jointly, yielding estimated coefficients of -3.928 and -4.128 , respectively. Similarly, we find that the probability of location is somewhat more sensitive to the international tax rate than to the host country tax rate variables.

Finally, regression 5 includes a separate host country corporate tax rate, non-resident withholding tax rate, and parent country corporate tax rate. Parameter estimates for the host country tax rate and parent country corporate tax rate are found to be negative and statistically significant, while the non-resident dividend withholding tax rate enters with a statistically insignificant coefficient. A one percentage point increase in the host country and parent country tax rates is significantly estimated to reduce the probability of location by 
0.761 and 1.002 percent, respectively, while the analogous effect of the non-resident withholding tax rate is estimated to be insignificant at 0.179 .

The relatively large effect of the parent-country corporate tax rate is surprising, as this tax can generally be deferred until dividend repatriation and it is further diminished by the potential in some countries for so-called worldwide income averaging. This latter practice allows multinationals resident in, for instance, the U.S. to claim foreign tax credits for foreign taxes paid in high-tax countries against U.S. taxes due on income from low-tax countries. To explain why the parent tax rate may be relatively important, note that this tax is borne by potential parent firms from a particular country, and not by parent firms from other countries or by local firms. The parent country tax thus puts the affected parent firms at a comparative disadvantage at owning assets in a host country vis-à-vis other potential owners. Withholding taxes, of course, also put foreign owners at a comparative disadvantage at owning local assets vis-à-vis local owners. However, non-resident dividend withholding taxes tend to vary relatively little across residents of different foreign parent countries. At the same time, withholding taxes in many instances are zero and otherwise are quite low. This could explain the apparent insensitivity of subsidiary location decisions to the withholding $\operatorname{tax}$.

\subsection{Robustness tests}

In an extension, we consider that a new subsidiary can be located either abroad or at home. To do this, we include episodes where a domestic subsidiary is established in the sample so that the number of potential national locations increases from 32 countries to 33 countries. Analogously to regression 1 of Table 5, we estimate an effective tax rate effect noting that the domestic option increases the sample size from 26,567 to 51,061 . The estimated coefficient for the effective tax is -1.465 , which is less than the corresponding 
estimate of -3.964 in regression 1 of Table 5. A one percentage point increase in the effective tax is now estimated to reduce the probability of location by 0.241 percent rather than 0.615 percent before. These results suggest that the choice between a domestic location and any foreign location is less tax sensitive than the choice among the set of foreign locations. In line with this, Devereux and Griffith (1998) have found that the decision of U.S. multinationals to locate abroad - in either France, Germany or the United Kingdom - is not tax sensitive, while the choice to locate in any of these three countries does depend on taxation.

A country's attractiveness as a location for new subsidiaries is potentially affected by unobserved country characteristics. In fact, some of the unobserved drivers of location may be country-pair specific. To account for this, we next include country-pair fixed effects in the estimation. However, the unobserved determinants of, say, German FDI in Poland may be different from the determinants of Polish FDI in Germany. To allow for such asymmetry in bilateral fixed effects, we in fact include two fixed effects for each country-pair, one for the case where a particular country is the parent country rather than the subsidiary country, and vice versa. The inclusion of bilateral fixed effects forces us to drop time-invariant bilateral variables from the estimation (the dropped variables are Contiguity, Origin of Law, and EU membership subsidiary). The estimation results of a linear probability model of foreign subsidiary location including the effective tax rate and bilateral fixed effects are presented in column 2 in Table 6. Estimation is by OLS rather than by the conditional logit technique to obtain convergent results. The effective tax rate obtains a significant coefficient of -0.098 , which suggests that a one percentage point increase of the effective tax rate reduces the probability of foreign subsidiary location by 0.098 percent. Thus, the inclusion of bilateral fixed effects and the switch to estimation by OLS jointly reduce the estimated tax sensitivity of the foreign subsidiary location choice considerably. 
A linear probability model that includes separate host country, withholding and parent country taxes is reported in column 3 , yielding a significant coefficient of -0.109 for the host country tax while the withholding and parent country taxes obtain statistically insignificant coefficients. The insignificance of these latter variables in a model including bilateral fixed effects is not surprising given that most of the variation in tax rates in our sample is crosssectional rather than time-variant. ${ }^{9}$

Next, we recognize that a multinational may establish a subsidiary in more than one foreign country in a given year. Specifically, for a multinational that establishes subsidiaries in $\mathrm{n}$ foreign countries in a given year, we organize the data so that there are $\mathrm{n}$ observations of 1 indicating a new foreign subsidiary and 32 minus $\mathrm{n}$ observations of 0 indicating no new foreign subsidiary. In this way, we recognize that the 32 potential foreign location choices are independent so that location in one foreign country does not preclude location in another foreign country. We re-estimate regressions 1 and 5 of Table 5 after structuring the data in this fashion and report the results as regressions 4 and 5 of Table 6 . The results are qualitatively very similar to those reported before.

Our sample of subsidiary location includes new subsidiaries only in the years they are established. This way, we cannot control for unobserved factors that may cause a particular foreign subsidiary to have a preference for subsidiary location in a particular foreign country. Some multinationals, however, no doubt are drawn to particular foreign countries on account of, say, specific public investments in infrastructure. To allow for such unobserved firmspecific factors, we next estimate a model of foreign subsidiary location using the Chamberlain technique. This technique uses the entire time series of a foreign subsidiary's existence rather than data for only the year in which a new subsidiary is established. This way, a change in a foreign subsidiary's status (i.e., its creation or its discontinuation) can be

\footnotetext{
${ }^{9}$ We also estimated boostrapped standard errors to allow for potential within-group correlation across parent
} 
related to a change in the international tax system and any other explanatory variable, thereby effectively controlling for time-invariant, multinational-specific determinants of foreign subsidiary location (see Hamerle and Ronning, 1995).

Using the Chamberlain technique, we re-estimate regressions 1 and 5 of Table 5, with the results reported as regressions 6 and 7 in Table 6 . The effective tax rate now enters regression 6 in Table 6 with an estimated coefficient of -3.618 that is statistically significant. An increase in the effective tax by one percentage point is now estimated to reduce the probability of location by 0.633 percent, which is very similar to the analogous estimate of 0.615 percent before. The separate host country withholding and parent country corporate taxes in turn obtain estimated coefficients of $-3.254,-3.402$ and -5.415 , respectively, that are all statistically significant. The corresponding semi-elasticities are estimated to be -0.704 , 0.736 , and -1.171 , respectively, and are all statistically significant.

\subsection{The dimensions of the subsidiary location problem and estimated tax sensitivities}

Our estimation considers foreign subsidiary location among a rather large set of 32 foreign countries. Other studies, as discussed in the introduction, typically consider fewer potential foreign locations. Devereux and Griffith (1998), for instance, consider location choices of U.S. multinationals among three European countries. The number of countries that a multinational can choose from (in a given set of countries) can be seen as one of the 'dimensions' of the location choice problem. Another main dimension of the location problem is the number of foreign subsidiaries that a multinational wishes to establish given the number of countries that it can choose from. Our large cross-country data set allows us to investigate whether and how these dimensions affect the estimated tax sensitivities of location choices.

countries in regression 1 of Table 5 and obtained qualitatively similar results. 
To start, we consider the role of the number of countries that a multinational can choose from. A smaller number of potential locations increases the average probability of location in any one country. At the same time, we can expect the sensitivity of the probability of location to taxation in a country to be higher if there are fewer location options. To investigate this, we shrink the number-of-countries dimension of our data set as much as possible. To be precise, we go from multinationals that can choose one of 32 foreign locations to multinationals that can choose one of two foreign locations. To implement this, we specifically consider the establishment of new foreign subsidiaries by multinationals located in one of three countries (either France, Germany or the United Kingdom) in one of two countries (two of the same three countries). ${ }^{10}$ Otherwise the estimation approach is analogous to regression 1 of Table 5 .

As reported in column 1 of Table 6, this shrinking of the number-of-countries dimension of the data set reduces the sample size to 735 observations. The estimated coefficient for the effective tax rate is more negative than before at -11.633 and statistically significant. This suggests that location is rather tax sensitive if there are few location options. However, the estimated semi-elasticity of location with respect to the effective tax is insignificantly estimated as -0.008 .

Next, we consider how the estimated tax sensitivity of location varies with the number of foreign subsidiaries a firm wishes to operate. For this purpose, we return to a scenario where multinationals can operate foreign subsidiaries in any of the 32 foreign European countries. At one extreme, a multinational wishes to operate exactly one subsidiary abroad. In that instance, the probability of location in any one country is small, and the sensitivity of the location probability to taxation is expected to be small as well. At the other extreme, a multinational may want to operate subsidiaries in all foreign countries. The probability of

\footnotetext{
${ }^{10}$ Note that these are the same three countries considered by Devereux and Griffith (1998). We, however,
} 
location in a foreign country in this case is one, and the location is completely insensitive to taxation. For intermediate values of foreign subsidiaries, the probability of location is less than one yet not insignificant and this probability is expected to be affected by taxation. This reasoning suggests that the tax sensitivity of location choices depends on the number of desired foreign subsidiaries and, more specifically, that this sensitivity may be hump-shaped in the number of foreign subsidiaries.

We first examine how the tax sensitivity of location depends on the number of new foreign subsidiaries that a multinational establishes over the 1999-2003 sample period. We specifically estimate logit models analogous to regression 1 of Table 5 separately for the cases where the multinational exactly establishes one, two, or three new foreign subsidiaries. In columns 1-3, we see that the estimated coefficients for the effective tax variable are -3.517 , -6.924 and -4.692 , respectively. The corresponding marginal effects of the effective tax on the probability of location are estimated to be $-0.430,-1.504$ and -0.952 , although only the second of these sensitivities is estimated to be statistically significant. These results suggest that the tax sensitivity of the location probability peaks for multinationals that aim to establish exactly two new foreign subsidiaries over the 1999-2003 sample period. The rather small number of multinationals that establish exactly four or any higher number of new foreign subsidiaries precludes us from estimating with precision analogous regressions for higher numbers of new foreign subsidiaries. As an alternative, however, we estimate a single regression using the entire sample where we interact the effective tax rate with dummy variables signaling that the multinational wishes to establish exactly one, two, three, four, five, or more than five new foreign subsidiaries. The estimated coefficients in column 4 of the table suggest that the marginal effects of taxation on the location probability peaks for multinationals that establish exactly four new foreign subsidiaries. A low estimated tax 
sensitivity of location for the case of three new foreign subsidiaries prevents the pattern of estimated coefficients to be fully hump-shaped. Overall, our results suggest that the tax sensitivity of location indeed varies with the 'flow' of new foreign subsidiaries during the sample period.

As an alternative, we next consider whether the tax sensitivity of the location choice depends on a multinational's 'stock' of foreign investment in existence at a certain point in time. Specifically, we will consider how the tax sensitivity of location depends on the number of countries where a multinational operates at least one foreign subsidiary using data only for 1999, established prior to or in 1999. We refocus the analysis on the number of countries rather than the number of foreign subsidiaries, as our tax data in fact distinguish national locations. ${ }^{11}$ Columns 1 to 5 of Table 8 report the results of regressions where we consider subsamples of multinationals operating in exactly one, two, three, four, or five countries. The estimated coefficients for the effective tax variables are statistically significant in all five regressions, apart from the one where the multinational operates in four countries. The estimated coefficients that are statistically significant display a hump-shaped pattern, with the estimated coefficient peaking for the case where the multinational operates in exactly two countries. Alternatively, regression 6 in the Table includes interaction terms of the effective tax variable with dummy variables signaling that the multinational operates in exactly one, two, three, four, five, or more than five countries. Four of the six effective tax variables obtain statistically significant coefficients. These four variables again display a hump-shaped pattern, with the estimated tax sensitivity of location peaking for multinationals that operate foreign subsidiaries in exactly four countries. Overall, our results support the hypothesis that estimated tax sensitivities of location can be plotted against a multinational's number of countries of operation in the form of an inverted $U$ curve.

multinationals choose one of the three if they wish to have a subsidiary abroad. 


\section{Empirical results on taxation and parent firm location}

There are several ways in which a multinational firm can bring about a tax efficient international structure. One important way, as considered in previous sections, is the location choice of foreign subsidiaries. Alternatively, a multinational may choose to relocate its parent firm to another country. One way to do this is through so-called corporate inversions whereby the previous parent firm becomes a foreign subsidiary and a previous foreign subsidiary becomes the parent. Desai and Hines (2002) find that inversions of U.S. multinationals are in part motivated by desire to avoid U.S. corporate income tax on foreign source income. Similarly, Voget (2008) finds evidence that international headquarter relocations are motivated by a desire to reduce international double taxation. Specifically, he finds that the likelihood of headquarters relocation increases in the difference between the home corporate income tax and the average of foreign subsidiaries' corporate income tax rates if a multinational resides in a country that provides foreign tax credits as double tax relief of host country taxation. In line with this, Huizinga and Voget (2008) find that the parent-subsidiary choice in cross-border mergers and acquisitions reflects international tax considerations.

Whether it is by choosing the subsidiary or the parent, the result should be that the observed distribution of parent-subsidiary relationships on average is tax efficient. In this section, we investigate whether this is the case for European multinationals with 1999 data. Specifically, for each multinational we consider the role of international taxation in the parent-subsidiary choice between the actual parent and any of its foreign subsidiaries.

Analogously to the effective tax rate introduced before, we now define the relative effective tax liability as the total tax if the parent firm were in a location A minus the total tax if the parent firm were in a location B, divided by the multinational's worldwide profits. If

\footnotetext{
${ }^{11}$ Firms that operate more than a single subsidiary in a certain foreign country may do so for a variety of reasons
} 
positive, the multinational would be better off locating the parent firm in country B rather than A, and we expect the probability of parent firm location in country A to be negatively related to the effective tax liability. Similarly, we define the relative withholding tax liability and the relative parent country tax liability, and we expect these relative tax liability variables to negatively affect parent firm location. Further, the relative corporate tax rate is defined as the tax rate in location $\mathrm{A}$ minus the tax rate in location $\mathrm{B}$, divided by the sum of the tax rates in the two locations. We include this variable in the regressions, even though we do not expect the relative corporate tax rate to affect the parent-subsidiary constellation independently of the relative tax liability variables. As a control variable, we next construct the relative size of assets defined as the size of assets in location A minus the size of assets in location $\mathrm{B}$, divided by the sum of assets in the two locations. In similar fashion, we define relative sales, GDP, per capita GDP and stock market development variables.

The results of logit regressions of the parent-subsidiary nexus are reported in Table 9. Regression 1 includes the relative effective tax liability as the only tax variable. This tax variable obtains a negative and significant coefficient to suggest that multinationals on average choose their structures so as to minimize their overall tax liabilities. The semielasticity of the probability of parent firm location is estimated to be rather sizeable at -3.074 . The relative corporate tax rate obtains a negative coefficient but it is not statistically significant. Among the controls, the relative sales variable obtains a negative and statistically significant coefficient to suggest that parent firms tend to generate relatively few sales. As reported in the table, the model has a reasonable goodness of fit as it correctly predicts parent firm location in 73.4 percent of the cases.

Regression 2 includes separate relative withholding tax and parent country tax liability variables. Both variables obtain negative coefficients that are not significant. 
Regressions 3 and 4 instead include only the relative parent country tax liability and relatively withholding tax liability, respectively. The parent tax liability variable obtains a negative and significant coefficient in regression 3, while the withholding tax liability variable has a negative and insignificant coefficient in regression 4.

Finally, regression 5 includes the relative corporate tax variable to the exclusion of all relative tax liability variables. As before, the relative corporate tax variable obtains a negative but insignificant coefficient.

Overall, our results indicate that the structure of multinational firms reflects a desire to minimize the firm's overall worldwide tax liability. More precisely, there is evidence that multinational firms are designed so as to avoid parent-country corporate income taxation, while there is no evidence that non-resident withholding taxes affect the parent-subsidiary nexus.

\section{Conclusions}

This paper provides evidence on the implications of international taxation for the location and organizational form of multinational firms. Our analysis uses panel data on the structure of multinational firms in 33 European countries over the 1999-2003 period. This rich data set allows us to advance the literature on taxation and multinationals in three distinct ways.

First, our multi-country data set enables us to estimate the separate effects of host country corporate income taxation, host country non-resident dividend withholding taxation, and parent-country corporate income taxation location decisions of multinational firms.

Second, our dynamic data allow us to investigate several distinct facets of the relationship between taxation of multinational firm structure. Specifically, we address the traditional question of foreign subsidiary location for a given multinational firm, and in 
addition investigate the international distribution of multinational headquarters across countries at a particular moment in time.

Third, data for a large set of countries enables us to investigate how certain 'dimensions' of the multinational firm choice problem, and in particular how many foreign subsidiaries it aims to establish in how many countries, affect estimated tax sensitivities of location choices.

Our main result is that parent-country (double) corporate taxation has an independent, strongly negative effect on the probability of foreign subsidiary location in potential host countries, despite the fact that parent country taxation can generally be deferred until income is repatriated. This may reflect that a parent country's taxation is rather discriminatory as it only applies to parent firms residing in the parent country. The high sensitivity of foreign subsidiary location to the parent country tax suggests that this tax is particularly distortive. Paradoxically, the parent country tax may be particularly distortive on account of the foreign credit mechanism - aiming to alleviate international double taxation - as the foreign-tax credit mechanism produces a high variability of the (post credit) parent-country tax across foreign location choices.

Location decisions regarding the parent firm are similarly shown to be affected by parent-country taxation. Specifically, we find that the parent firm is less likely to be located in countries with relatively high foreign-source income.

Our investigation of the 'dimensions' of the foreign subsidiary location problem shows that estimated tax sensitivities of location decisions vary with the number of countries considered as well as with the number of a multinational's foreign subsidiaries. Specifically, we find some evidence that estimated tax coefficients are larger for a smaller number of potential foreign location countries in the analysis. Further, we find support for the hypothesis that tax sensitivities are largest for multinationals that invest in an intermediate 
number of foreign countries (between the minimum of 1 and the maximum equal to the number of foreign countries in the analysis). These results together suggest that estimates of the impact of taxation on international location decisions are best based on data for many countries and ideally should take into account an apparent heterogeneity regarding the desired scale of investment among multinational firms.

Overall, our results show that parent-country taxation is instrumental in shaping the structure of multinational enterprise. These results have potentially important implications for tax policies at the national and international level. While the focus of this paper has been on the impact of parent-country taxation on multinational-firm structure, it should be recognized that such taxation in addition may distort capital investment and financing decisions once a firm's international structure has been established. 


\section{References}

Barrios, S., H. Görg and E. Strobl, 2005, Foreign direct investment, competition and industrial development in the host country, European Economic Review 49, 1761-1784.

Buettner, T. and M. Ruf, 2007, Tax incentives and the location of FDI: Evidence from a panel of German multinationals, International Tax and Public Finance 14, 151-164.

Bartik, T., 1985, Business Location decision in the United States: Estimates of the effects of unionization, taxes, and other characteristics of states, Journal of Economics and Business Statistics 3, 14-22.

Carlton, D.W., 1983, The location and employment choices of new firms: An econometric model with discrete and continuous endogenous variables, Review of Economics and Statistics 65, 440-49.

Chamberlain, 1980, Analysis of covariance with qualitative data, Review of Economic Studies 47, 225-238.

Desai, M. A. and J.R. Hines, 2002, Expectations and expatriations: Tracing the causes and consequences of corporate inversions, National Tax Journal 55, 409-440.

Devereux, M.P. and R. Griffith, 1998, Taxes and the location of production: Evidence from a panel of US multinationals, Journal of Public Economics. 68, 335-367.

Devereux, M.P. and G. Maffini, 2007, The impact of taxation on the location of capital, firms and profit: A survey of empirical evidence, Oxford University Centre for Business Taxation Working Paper 07/02.

Görg, H. and D. Greenaway, 2004, Much ado about nothing? Do domestic firms really benefit from foreign direct investment?, World Bank Research Observer 19, 171-197.

Hamerle, A. and G. Ronning, 1995, Panel analysis for qualitative variables. In: Argminger, G., C.C. Clogg and M.E. Sobel (Eds.), Handbook of Statistical Modeling for the Social and Behavioural Sciences, 401-451 (Plenum, New York, Plenum).

Hines, J.R., 1996, Altered states: Taxes and the location of foreign direct investment in America, American. Economic Review 86, 1076-1094.

Huizinga, H, L. Laeven and G. Nicodème, 2008, Capital structure and international debt shifting, Journal of Financial Economics 88, 80-118

Huizinga, H. and J. Voget, 2008, International Taxation and the Direction and Volume of Cross-Border M\&As, forthcoming in Journal of Finance.

Hoffman, S.D. and G.J. Duncan, 1988, Multinomial and conditional logit discrete-choice models in demography, Demography.25, 415-427.

Kemsley, D., 1998, The Effect of Taxes on Production Location, Journal of Accounting Research 36, 321-341 
Kravis, I.B. and R.E. Lipsey, 1982, The location of overseas production and production for export by U.S. multinational firms, Journal of International Economics 12, 201-223.

La Porta, R., F. Lopez-de-Silanes, A. Shleifer, A and R.W. Vishny, 1998, Law and Finance, Journal of Political Economy 106, 1113-1155.

Mayer T. and G. Ottaviano, 2007, The happy few: new facts on the internationalisation of European firms, Bruegel-CEPR EFIM 2007 Report, Bruegel Blueprint Series.

McFadden, D., 1974, Conditional logit analysis of qualitative choice behavior, in P. Zarembka (ed.), Frontiers in Econometrics 105-142 (Academic Press, New York).

McFadden, D., 1976, A comment on discriminant analysis versus logit analysis, Annals of Economic and Social Measurement. 5, 511-523.

Mooij, de R. and S. Ederveen, 2006, What a difference does it make? Understanding the empirical literature on taxation and international capital flows, Economic Papers No. 261, European Commission, D-G for Economic and Financial Affairs, Brussels.

Voget, J., 2008, Headquarter relocations and international taxation, mimeo, Centre for Business Taxation, Oxford University. 
Table 1. Corporate taxation and double-tax relief methods for dividend received in European countries in 2003

\begin{tabular}{|c|c|c|c|}
\hline & Corporate tax rate & Treatment of foreign dividends from treaty countries & Treatment of foreign dividends from non-treaty countries \\
\hline Austrias & 24 & Exemption & Exemption \\
\hline Belgium & 33.99 & Exemption (up to $95 \%$ ) & Exemption (up to $95 \%$ ) \\
\hline Bulgaria & 23.5 & Indirect credit & Direct credit \\
\hline Croatia & 20 & Exemption & Exemption \\
\hline Cyprus & 15 & Exemption & Exemption \\
\hline Czech Republic & 31 & Indirect credit & Deduction \\
\hline Denmark & 30 & Exemption & Exemption \\
\hline Estonia & 26 & Indirect credit & Indirect credit \\
\hline Finland & 29 & Exemption & Direct credit \\
\hline France & 35.43 & Exemption (up to $95 \%$ ) & Exemption (up to $95 \%$ ) \\
\hline Germany & 39.59 & Exemption (up to $95 \%$ ) & Exemption (up to $95 \%$ ) \\
\hline Greece & 35 & Indirect credit & Indirect credit \\
\hline Hungary & 19.64 & Exemption & Exemption \\
\hline Iceland & 18 & Exemption & Exemption \\
\hline Ireland & 12.5 & Indirect credit & Indirect credit \\
\hline Italy & 38.25 & Exemption (up to $60 \%$ ) & Exemption (up to $60 \%$ ) \\
\hline Latvia & 19 & Exemption & Exemption \\
\hline Lithuania & 15 & Exemption & Exemption \\
\hline Luxembourg & 30.38 & Exemption & Exemption \\
\hline Malta & 35 & Indirect credit & Indirect credit \\
\hline Netherlands & 34.5 & Exemption & Exemption \\
\hline Norway & 28 & Indirect credit & Indirect credit \\
\hline Poland & 27 & Indirect credit & Direct Credit \\
\hline Portugal & 33 & Direct credit & Direct credit \\
\hline Romania & 25 & Indirect credit & Indirect credit \\
\hline Russia & 24 & Direct credit & No relief \\
\hline Slovak Republic & 25 & Indirect credit & No relief \\
\hline Slovenia & 25 & Exemption & Exemption \\
\hline Spain & 35 & Exemption & Indirect credit \\
\hline Sweden & 28 & Exemption & Exemption \\
\hline Switzerland & 21.74 & Exemption & Exemption \\
\hline Turkey & 33 & Indirect credit & Direct credit \\
\hline United Kingdom & 30 & Indirect credit & Indirect credit \\
\hline $\begin{array}{l}\text { Note: Statutory corp } \\
\text { surcharge for large } \\
\text { includes a deductibl } \\
\text { local taxes. Corpora } \\
\text { subsidiaries are assu } \\
\text { bilateral treaty or th } \\
\text { withholding tax is } n\end{array}$ & $\begin{array}{l}\text { on retained ea } \\
\text { of Germany in } \\
\text { te tax rate of Ire }\end{array}$ & $\begin{array}{l}26 \% \text { is applied on distributed profit. Corpc } \\
5.5 \% \text {, an average deductible trade tax of } 1 \\
\text { For non-trading activities, the rate is } 25 \% \\
\text { al and local taxes in Zurich. Treatment re } \\
\text { ds from treaty countries in Poland as long } \\
\text { treaty countries are exempt from corpora } \\
\text { o a certain percentage, indicated between }\end{array}$ & $\begin{array}{l}\text { \& rate of France includes a } 3 \% \text { social surcharge and a special } 3.3 \% \\
\text { and an exceptional surcharge of } 1.5 \% \text {. Corporate tax rate of Hungar } \\
\text { orate tax rate of Luxembourg includes employment surcharges and } \\
\text { louble tax relief convention used by parent country. Foreign } \\
\text { olding stake is at least } 75 \% \text { for the past two years and there exists a } \\
\text { if the EU parent-subsidiary directive applies (but the foreign } \\
\text { Source : International Bureau of Fiscal Documentation. }\end{array}$ \\
\hline
\end{tabular}


Table 2. Bilateral withholding tax rates in Europe in 2003

\begin{tabular}{|c|c|c|c|c|c|c|c|c|c|c|c|c|c|c|c|c|c|c|c|c|c|c|c|c|c|c|c|c|c|c|c|c|c|}
\hline 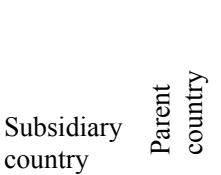 & $\begin{array}{l}\stackrel{\mathscr{m}}{E} \\
\stackrel{\underline{m}}{Z}\end{array}$ & 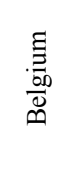 & 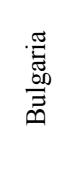 & 茎 & 总 & 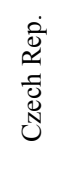 & $\begin{array}{l}\overline{\bar{\Xi}} \\
\text { 苂 } \\
\text { ص }\end{array}$ & . & 丞 & 节 & 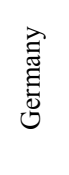 & 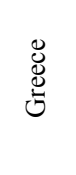 & 密 & 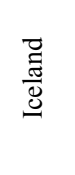 & 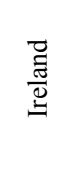 & 吾 & 茎 & 㺃 & 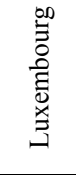 & $\frac{\sqrt{3}}{\Sigma}$ & 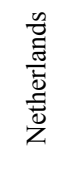 & 胥 & 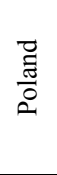 & 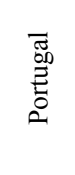 & 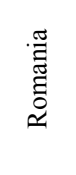 & 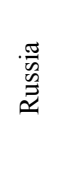 & $\begin{array}{l}\frac{\tilde{D}}{\tilde{a}} \\
\frac{\pi}{\pi} \\
\frac{0}{\omega}\end{array}$ & 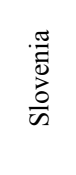 & 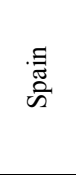 & 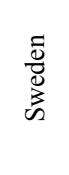 & 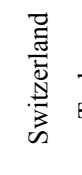 & 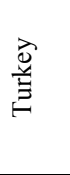 & 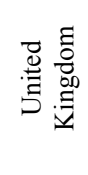 \\
\hline Austria & $\mathrm{X}$ & 0 & 0 & 0 & 10 & 10 & 0 & 5 & 0 & 0 & 0 & 0 & 10 & 25 & 0 & 0 & 25 & 25 & 0 & 15 & 0 & 5 & 10 & 0 & 15 & 5 & 10 & 5 & 0 & 0 & 0 & 25 & 0 \\
\hline Belgium & 0 & $\mathrm{X}$ & 10 & 10 & 10 & 5 & 0 & 25 & 0 & 0 & 0 & 0 & 10 & 25 & 0 & 0 & 25 & 25 & 0 & 15 & 0 & 5 & 10 & 0 & 5 & 10 & 5 & 5 & 0 & 0 & 10 & 15 & 0 \\
\hline Bulgaria & 0 & 10 & $\mathrm{X}$ & 5 & 5 & 10 & 5 & 15 & 10 & 5 & 15 & 10 & 10 & 15 & 5 & 10 & 15 & 15 & 5 & 0 & 5 & 15 & 10 & 10 & 10 & 15 & 10 & 15 & 5 & 10 & 5 & 10 & 10 \\
\hline Croatia & 0 & 10 & 5 & $\mathrm{X}$ & 10 & 5 & 5 & 15 & 5 & 5 & 0 & 5 & 5 & 15 & 15 & 10 & 5 & 15 & 15 & 5 & 5 & 15 & 5 & 15 & 5 & 5 & 5 & 15 & 5 & 15 & 5 & 10 & 5 \\
\hline Cyprus & 0 & 0 & 0 & 0 & $\mathrm{X}$ & 0 & 0 & 0 & 0 & 0 & 0 & 0 & 0 & 0 & 0 & 0 & 0 & 0 & 0 & 0 & 0 & 0 & 0 & 0 & 0 & 0 & 0 & 0 & 0 & 0 & 0 & 0 & 0 \\
\hline Czech Rep. & 10 & 5 & 10 & 5 & 10 & $\mathrm{X}$ & 15 & 5 & 5 & 10 & 5 & 15 & 5 & 5 & 5 & 15 & 5 & 5 & 5 & 5 & 0 & 5 & 5 & 10 & 10 & 10 & 5 & 5 & 5 & 0 & 5 & 15 & 5 \\
\hline Denmark & 0 & 0 & 5 & 5 & 10 & 15 & $\mathrm{X}$ & 5 & 0 & 0 & 0 & 0 & 5 & 0 & 0 & 0 & 5 & 5 & 0 & 0 & 0 & 0 & 0 & 0 & 10 & 10 & 15 & 5 & 0 & 0 & 0 & 15 & 0 \\
\hline Estonia & 0 & 0 & 0 & 0 & 0 & 0 & 0 & $\mathrm{X}$ & 0 & 0 & 0 & 0 & 0 & 0 & 0 & 0 & 0 & 0 & 0 & 0 & 0 & 0 & 0 & 0 & 0 & 0 & 0 & 0 & 0 & 0 & 0 & 0 & 0 \\
\hline Finland & 0 & 0 & 10 & 5 & 29 & 0 & 0 & 0 & X & 0 & 0 & 0 & 5 & 0 & 0 & 0 & 0 & 0 & 0 & 0 & 0 & 0 & 0 & 0 & 0 & 0 & 0 & 5 & 0 & 0 & 0 & 15 & 0 \\
\hline France & 0 & 0 & 5 & 5 & 10 & 10 & 0 & 5 & 0 & $\mathrm{X}$ & 0 & 0 & 5 & 5 & 0 & 0 & 5 & 5 & 0 & 5 & 0 & 0 & 5 & 0 & 10 & 10 & 10 & 5 & 0 & 0 & 5 & 15 & 0 \\
\hline Germany & 0 & 0 & 15 & 15 & 10 & 5 & 0 & 5 & 0 & 0 & $\mathrm{X}$ & 0 & 5 & 5 & 0 & 0 & 5 & 5 & 0 & 5 & 0 & 0 & 5 & 0 & 10 & 5 & 5 & 15 & 0 & 0 & 0 & 15 & 0 \\
\hline Greece & 0 & 0 & 0 & 0 & 0 & 0 & 0 & 0 & 0 & 0 & 0 & $\mathrm{X}$ & 0 & 0 & 0 & 0 & 0 & 0 & 0 & 0 & 0 & 0 & 0 & 0 & 0 & 0 & 0 & 0 & 0 & 0 & 0 & 0 & 0 \\
\hline Hungary & 10 & 10 & 10 & 10 & 5 & 5 & 5 & 20 & 5 & 5 & 5 & 10 & X & 20 & 5 & 10 & 20 & 20 & 5 & 5 & 5 & 10 & 10 & 10 & 5 & 10 & 5 & 10 & 5 & 5 & 10 & 10 & 5 \\
\hline Iceland & 15 & 15 & 15 & 15 & 15 & 5 & 0 & 5 & 0 & 5 & 5 & 15 & 15 & X & 15 & 15 & 5 & 5 & 5 & 15 & 0 & 0 & 5 & 10 & 15 & 15 & 15 & 15 & 5 & 0 & 5 & 15 & 5 \\
\hline Ireland & 0 & 0 & 0 & 20 & 0 & 0 & 0 & 0 & 0 & 0 & 0 & 20 & 0 & 20 & $\mathrm{X}$ & 0 & 0 & 0 & 0 & 20 & 0 & 0 & 0 & 0 & 0 & 0 & 0 & 0 & 0 & 0 & 0 & 20 & 0 \\
\hline Italy & 0 & 0 & 10 & 10 & 15 & 15 & 0 & 5 & 0 & 0 & 0 & 0 & 10 & 27 & 0 & 0 & 27 & 5 & 0 & 15 & 0 & 15 & 10 & 0 & 10 & 5 & 15 & 10 & 0 & 0 & 15 & 15 & 0 \\
\hline Latvia & 10 & 10 & 10 & 5 & 10 & 5 & 5 & 5 & 5 & 5 & 5 & 10 & 10 & 5 & 5 & 10 & $\mathrm{X}$ & 0 & 10 & 5 & 5 & 5 & 5 & 10 & 10 & 10 & 10 & 5 & 10 & 5 & 5 & 10 & 5 \\
\hline Lithuania & 15 & 15 & 15 & 5 & 15 & 5 & 5 & 0 & 5 & 5 & 5 & 15 & 15 & 5 & 5 & 5 & 0 & $\mathrm{X}$ & 15 & 15 & 5 & 5 & 5 & 15 & 10 & 15 & 10 & 5 & 5 & 5 & 5 & 10 & 5 \\
\hline Luxembourg & 0 & 0 & 0 & 20 & 20 & 0 & 0 & 20 & 0 & 0 & 0 & 0 & 0 & 0 & 0 & 0 & 20 & 20 & $\mathrm{X}$ & 0 & 0 & 0 & 0 & 0 & 0 & 0 & 0 & 0 & 0 & 0 & 0 & 20 & 0 \\
\hline Malta & 0 & 0 & 0 & 0 & 0 & 0 & 0 & 0 & 0 & 0 & 0 & 0 & 0 & 0 & 0 & 0 & 0 & 0 & 0 & $\mathrm{X}$ & 0 & 0 & 0 & 0 & 0 & 0 & 0 & 0 & 0 & 0 & 0 & 0 & 0 \\
\hline Netherlands & 0 & 0 & 5 & 0 & 25 & 0 & 0 & 5 & 0 & 0 & 0 & 0 & 5 & 0 & 0 & 0 & 5 & 5 & 0 & 5 & $\mathrm{X}$ & 0 & 0 & 0 & 0 & 5 & 0 & 5 & 0 & 0 & 0 & 5 & 0 \\
\hline Norway & 5 & 15 & 15 & 15 & 0 & 5 & 0 & 5 & 0 & 0 & 0 & 20 & 10 & 0 & 0 & 15 & 5 & 5 & 5 & 15 & 0 & $\mathrm{X}$ & 5 & 10 & 10 & 10 & 5 & 15 & 10 & 0 & 5 & 20 & 5 \\
\hline Poland & 10 & 10 & 10 & 5 & 10 & 5 & 5 & 5 & 5 & 5 & 5 & 15 & 10 & 5 & 0 & 10 & 5 & 5 & 5 & 5 & 0 & 5 & $\mathrm{X}$ & 10 & 5 & 10 & 5 & 5 & 5 & 5 & 5 & 10 & 5 \\
\hline Portugal & 0 & 0 & 15 & 30 & 30 & 15 & 0 & 30 & 0 & 0 & 0 & 0 & 15 & 15 & 0 & 0 & 30 & 30 & 0 & 15 & 0 & 15 & 15 & $\mathrm{X}$ & 15 & 15 & 30 & 30 & 0 & 0 & 15 & 30 & 0 \\
\hline Romania & 10 & 5 & 10 & 5 & 10 & 10 & 10 & 10 & 5 & 10 & 10 & 10 & 5 & 10 & 3 & 10 & 10 & 10 & 5 & 5 & 5 & 10 & 5 & 10 & $\mathrm{X}$ & 10 & 10 & 5 & 10 & 10 & 10 & 10 & 10 \\
\hline Russia & 5 & 15 & 15 & 5 & 0 & 10 & 10 & 15 & 5 & 5 & 5 & 15 & 10 & 15 & 10 & 5 & 15 & 15 & 10 & 15 & 5 & 10 & 10 & 10 & 15 & $\mathrm{X}$ & 10 & 10 & 5 & 5 & 5 & 10 & 10 \\
\hline Slovak Rep. & 10 & 5 & 10 & 5 & 10 & 5 & 15 & 15 & 5 & 10 & 5 & 15 & 5 & 15 & 0 & 15 & 10 & 10 & 5 & 5 & 0 & 5 & 5 & 15 & 10 & 10 & $X$ & 5 & 5 & 0 & 5 & 5 & 5 \\
\hline Slovenia & 5 & 5 & 15 & 15 & 10 & 5 & 5 & 15 & 5 & 5 & 15 & 15 & 10 & 15 & 5 & 10 & 5 & 5 & 5 & 15 & 5 & 15 & 5 & 15 & 15 & 10 & 5 & $\mathrm{X}$ & 5 & 5 & 5 & 15 & 5 \\
\hline Spain & 0 & 0 & 5 & 15 & 15 & 5 & 0 & 15 & 0 & 0 & 0 & 0 & 5 & 5 & 0 & 0 & 15 & 15 & 0 & 15 & 0 & 10 & 5 & 0 & 5 & 5 & 5 & 5 & $\mathrm{X}$ & 0 & 10 & 15 & 0 \\
\hline Sweden & 0 & 0 & 0 & 0 & 0 & 0 & 0 & 0 & 0 & 0 & 0 & 0 & 0 & 0 & 0 & 0 & 0 & 0 & 0 & 0 & 0 & 0 & 0 & 0 & 0 & 0 & 0 & 0 & 0 & $\mathrm{X}$ & 0 & 0 & 0 \\
\hline Switzerland & 5 & 10 & 5 & 35 & 35 & 5 & 0 & 35 & 5 & 5 & 5 & 5 & 10 & 5 & 10 & 15 & 5 & 5 & 0 & 35 & 0 & 5 & 5 & 10 & 10 & 5 & 5 & 15 & 10 & 0 & $\mathrm{X}$ & 35 & 5 \\
\hline Turkey & 16.5 & 16.5 & 16.5 & 11 & 16.5 & 16.5 & 16.5 & 16.5 & 16.5 & 16.5 & 16.5 & 16.5 & 11 & 16.5 & 16.5 & 16.5 & 16.5 & 11 & 16.5 & 16.5 & 16.5 & 16.5 & 11 & 16.5 & 16.5 & 11 & 5.5 & 16.5 & 16.5 & 16.5 & 16.5 & $\mathrm{X}$ & 16.5 \\
\hline United Kingdom & 0 & 0 & 0 & 0 & 0 & 0 & 0 & 0 & 0 & 0 & 0 & 0 & 0 & 0 & 0 & 0 & 0 & 0 & 0 & 0 & 0 & 0 & 0 & 0 & 0 & 0 & 0 & 0 & 0 & 0 & 0 & 0 & $\mathrm{X}$ \\
\hline
\end{tabular}


Table 3. Existence of a bilateral tax treaties for European country pairs in 2003

\begin{tabular}{|c|c|c|c|c|c|c|c|c|c|c|c|c|c|c|c|c|c|c|c|c|c|c|c|c|c|c|c|c|c|c|c|c|c|}
\hline 咅 & 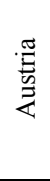 & 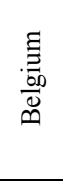 & 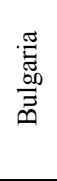 & $\begin{array}{l}\stackrel{g}{\mathbb{Z}} \\
\stackrel{0}{0} \\
ت\end{array}$ & 总 & 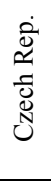 & 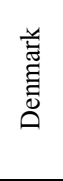 & 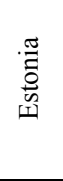 & 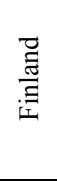 & 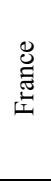 & $\begin{array}{l}\widehat{\overparen{\Xi}} \\
\stackrel{\Xi}{0} \\
\stackrel{0}{0}\end{array}$ & $\begin{array}{l}\ddot{U} \\
\dddot{̋} \\
\tilde{J}\end{array}$ & 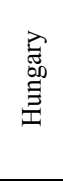 & 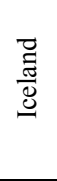 & $\begin{array}{l}\vec{\Xi} \\
\stackrel{\Xi}{\Xi} \\
\end{array}$ & $\overrightarrow{\vec{\Xi}}$ & 䔍 & 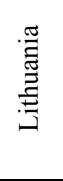 & 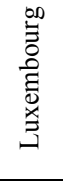 & $\frac{\stackrel{\pi}{\pi}}{\sum^{\pi}}$ & 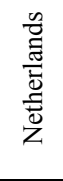 & $\begin{array}{l}\text { ते } \\
\stackrel{3}{0} \\
\text { Z }\end{array}$ & 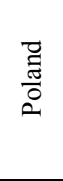 & $\begin{array}{l}\overline{J_{0}} \\
\vec{E} \\
\overline{0}\end{array}$ & 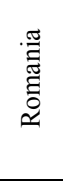 & 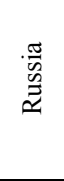 & $\begin{array}{l}\dot{a} \\
\stackrel{\sim}{\pi} \\
\frac{a}{\pi} \\
\frac{0}{\tilde{a}}\end{array}$ & 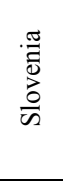 & $\begin{array}{l}\text { है } \\
\text { है }\end{array}$ & $\begin{array}{l}\bar{E} \\
\overline{0} \\
\bar{d} \\
\tilde{n}\end{array}$ & 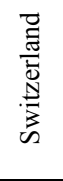 & 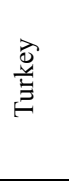 & 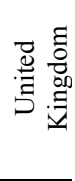 \\
\hline Austria & $\mathrm{X}$ & 1 & 1 & 1 & 1 & 1 & 1 & 1 & 1 & 1 & 1 & 1 & 1 & 0 & 1 & 1 & 0 & 0 & 1 & 1 & 1 & 1 & 1 & 1 & 1 & 1 & 1 & 1 & 1 & 1 & 1 & 1 & 1 \\
\hline Belgium & 1 & $\mathrm{X}$ & 1 & 1 & 1 & 1 & 1 & 0 & 1 & 1 & 1 & 1 & 1 & 0 & 1 & 1 & 0 & 0 & 1 & 1 & 1 & 1 & 1 & 1 & 1 & 1 & 1 & 1 & 1 & 1 & 1 & 1 & 1 \\
\hline Bulgaria & 1 & 1 & $\mathrm{X}$ & 1 & 1 & 1 & 1 & 0 & 1 & 1 & 1 & 1 & 1 & 0 & 1 & 1 & 0 & 0 & 1 & 1 & 1 & 1 & 1 & 1 & 1 & 0 & 1 & 0 & 1 & 1 & 1 & 0 & 1 \\
\hline Croatia & 1 & 1 & 0 & $\mathrm{X}$ & 1 & 1 & 1 & 0 & 1 & 1 & 1 & 1 & 1 & 0 & 0 & 1 & 1 & 1 & 0 & 0 & 1 & 1 & 1 & 0 & 1 & 1 & 1 & 0 & 0 & 1 & 0 & 0 & 1 \\
\hline Cyprus & 1 & 1 & 1 & 1 & $\mathrm{X}$ & 1 & 1 & 0 & 0 & 1 & 1 & 1 & 1 & 0 & 1 & 1 & 0 & 0 & 0 & 1 & 0 & 1 & 1 & 0 & 1 & 1 & 1 & 1 & 0 & 1 & 0 & 0 & 1 \\
\hline Czech Rep. & 1 & 1 & 1 & 1 & 1 & $\mathrm{X}$ & 1 & 1 & 1 & 1 & 1 & 1 & 1 & 1 & 1 & 1 & 1 & 1 & 1 & 0 & 1 & 1 & 1 & 1 & 1 & 1 & 1 & 1 & 1 & 1 & 1 & 0 & 1 \\
\hline Denmark & 1 & 1 & 1 & 1 & 1 & 1 & $\mathrm{X}$ & 1 & 1 & 1 & 1 & 1 & 1 & 1 & 1 & 1 & 1 & 1 & 1 & 1 & 1 & 1 & 1 & 0 & 1 & 1 & 1 & 1 & 1 & 1 & 1 & 1 & 1 \\
\hline Estonia & 0 & 0 & 0 & 0 & 0 & 1 & 1 & $X$ & 1 & 1 & 1 & 0 & 0 & 1 & 1 & 1 & 1 & 1 & 0 & 0 & 1 & 1 & 1 & 0 & 0 & 0 & 0 & 0 & 0 & 1 & 0 & 0 & 1 \\
\hline Finland & 1 & 1 & 1 & 1 & 0 & 1 & 1 & 1 & $\mathrm{X}$ & 1 & 1 & 1 & 1 & 1 & 1 & 1 & 1 & 1 & 1 & 1 & 1 & 1 & 1 & 1 & 1 & 1 & 1 & 1 & 1 & 1 & 1 & 1 & 1 \\
\hline France & 1 & 1 & 1 & 1 & 1 & 1 & 1 & 1 & 1 & $\mathrm{X}$ & 1 & 1 & 1 & 1 & 1 & 1 & 1 & 1 & 1 & 1 & 1 & 1 & 1 & 1 & 1 & 1 & 1 & 1 & 1 & 1 & 1 & 1 & 1 \\
\hline Germany & 1 & 1 & 1 & 1 & 1 & 1 & 1 & 1 & 1 & 1 & $\mathrm{X}$ & 1 & 1 & 1 & 1 & 1 & 1 & 1 & 1 & 1 & 1 & 1 & 1 & 1 & 1 & 1 & 1 & 1 & 1 & 1 & 1 & 1 & 1 \\
\hline Greece & 1 & 1 & 1 & 1 & 1 & 1 & 1 & 0 & 1 & 1 & 1 & $\mathrm{X}$ & 1 & 0 & 1 & 1 & 0 & 0 & 1 & 0 & 1 & 1 & 1 & 1 & 1 & 0 & 1 & 0 & 1 & 1 & 1 & 0 & 1 \\
\hline Hungary & 1 & 1 & 1 & 1 & 1 & 1 & 1 & 0 & 1 & 1 & 1 & 1 & X & 0 & 1 & 1 & 0 & 0 & 1 & 1 & 1 & 1 & 1 & 1 & 1 & 1 & 1 & 1 & 1 & 1 & 1 & 1 & 1 \\
\hline Iceland & 0 & 0 & 0 & 0 & 0 & 1 & 1 & 1 & 1 & 1 & 1 & 0 & 0 & $\mathrm{X}$ & 0 & 0 & 1 & 1 & 1 & 0 & 1 & 1 & 1 & 1 & 0 & 0 & 0 & 0 & 1 & 1 & 1 & 0 & 1 \\
\hline Ireland & 1 & 1 & 1 & 0 & 1 & 1 & 1 & 1 & 1 & 1 & 1 & 0 & 1 & 0 & $\mathrm{X}$ & 1 & 1 & 1 & 1 & 0 & 1 & 1 & 1 & 1 & 1 & 1 & 1 & 1 & 1 & 1 & 1 & 0 & 1 \\
\hline Italy & 1 & 1 & 1 & 1 & 1 & 1 & 1 & 1 & 1 & 1 & 1 & 1 & 1 & 0 & 1 & $X$ & 0 & 1 & 1 & 1 & 1 & 1 & 1 & 1 & 1 & 1 & 1 & 1 & 1 & 1 & 1 & 1 & 1 \\
\hline Latvia & 0 & 0 & 0 & 1 & 0 & 1 & 1 & 1 & 1 & 1 & 1 & 0 & 0 & 1 & 1 & 0 & $\mathrm{X}$ & 1 & 0 & 0 & 1 & 1 & 1 & 0 & 1 & 0 & 1 & 1 & 0 & 1 & 1 & 0 & 1 \\
\hline Lithuania & 0 & 0 & 0 & 1 & 0 & 1 & 1 & 1 & 1 & 1 & 1 & 0 & 0 & 1 & 1 & 1 & 1 & $\mathrm{X}$ & 0 & 0 & 1 & 1 & 1 & 0 & 1 & 0 & 1 & 1 & 0 & 1 & 1 & 0 & 1 \\
\hline Luxembourg & 1 & 1 & 1 & 0 & 0 & 1 & 1 & 0 & 1 & 1 & 1 & 1 & 1 & 1 & 1 & 1 & 0 & 0 & $\mathrm{X}$ & 1 & 1 & 1 & 1 & 1 & 1 & 1 & 1 & 1 & 1 & 1 & 1 & 0 & 1 \\
\hline Malta & 1 & 1 & 1 & 1 & 1 & 1 & 1 & 1 & 1 & 1 & 1 & 0 & 1 & 0 & 0 & 1 & 1 & 0 & 1 & $\mathrm{X}$ & 1 & 1 & 1 & 1 & 1 & 0 & 1 & 0 & 0 & 1 & 1 & 0 & 1 \\
\hline Netherlands & 1 & 1 & 1 & 1 & 0 & 1 & 1 & 1 & 1 & 1 & 1 & 1 & 1 & 1 & 1 & 1 & 1 & 1 & 1 & 1 & $\mathrm{X}$ & 1 & 1 & 1 & 1 & 1 & 1 & 1 & 1 & 1 & 1 & 1 & 1 \\
\hline Norway & 1 & 1 & 1 & 1 & 1 & 1 & 1 & 1 & 1 & 1 & 1 & 1 & 1 & 1 & 1 & 1 & 1 & 1 & 1 & 1 & 1 & $\mathrm{X}$ & 1 & 1 & 1 & 1 & 1 & 1 & 1 & 1 & 1 & 1 & 1 \\
\hline Poland & 1 & 1 & 1 & 1 & 1 & 1 & 1 & 1 & 1 & 1 & 1 & 1 & 1 & 1 & 1 & 1 & 1 & 1 & 1 & 1 & 1 & 1 & $\mathrm{X}$ & 1 & 1 & 1 & 1 & 1 & 1 & 1 & 1 & 1 & 1 \\
\hline Portugal & 1 & 1 & 1 & 0 & 0 & 1 & 1 & 0 & 1 & 1 & 1 & 1 & 1 & 1 & 1 & 1 & 0 & 0 & 1 & 1 & 1 & 1 & 1 & $\mathrm{X}$ & 1 & 1 & 1 & 0 & 1 & 0 & 1 & 0 & 1 \\
\hline Romania & 1 & 1 & 1 & 1 & 1 & 1 & 1 & 0 & 1 & 1 & 1 & 1 & 1 & 0 & 1 & 1 & 1 & 1 & 1 & 0 & 1 & 1 & 1 & 1 & $\mathrm{X}$ & 1 & 1 & 1 & 1 & 1 & 1 & 1 & 1 \\
\hline Russia & 1 & 1 & 1 & 1 & 1 & 1 & 1 & 0 & 1 & 1 & 1 & 0 & 1 & 0 & 1 & 1 & 0 & 0 & 1 & 0 & 1 & 1 & 1 & 1 & 1 & $\mathrm{X}$ & 1 & 0 & 1 & 1 & 1 & 1 & 1 \\
\hline Slovak Rep. & 1 & 1 & 1 & 1 & 1 & 1 & 1 & 0 & 1 & 1 & 1 & 1 & 1 & 0 & 1 & 1 & 1 & 1 & 1 & 1 & 1 & 1 & 1 & 1 & 1 & 1 & $\mathrm{X}$ & 1 & 1 & 1 & 1 & 1 & 1 \\
\hline Slovenia & 1 & 1 & 0 & 0 & 1 & 1 & 1 & 0 & 1 & 1 & 1 & 0 & 1 & 0 & 1 & 1 & 1 & 1 & 1 & 0 & 1 & 1 & 1 & 0 & 1 & 1 & 1 & $\mathrm{X}$ & 1 & 1 & 1 & 0 & 1 \\
\hline Spain & 1 & 1 & 1 & 0 & 0 & 1 & 1 & 0 & 1 & 1 & 1 & 1 & 1 & 1 & 1 & 1 & 0 & 0 & 1 & 0 & 1 & 1 & 1 & 1 & 1 & 1 & 1 & 1 & $\mathrm{X}$ & 1 & 1 & 0 & 1 \\
\hline Sweden & 1 & 1 & 1 & 1 & 1 & 1 & 1 & 1 & 1 & 1 & 1 & 1 & 1 & 1 & 1 & 1 & 1 & 1 & 1 & 1 & 1 & 1 & 1 & 1 & 1 & 1 & 1 & 1 & 1 & $\mathrm{X}$ & 1 & 1 & 1 \\
\hline Switzerland & 1 & 1 & 1 & 0 & 0 & 1 & 1 & 0 & 1 & 1 & 1 & 1 & 1 & 1 & 1 & 1 & 1 & 1 & 1 & 1 & 1 & 1 & 1 & 1 & 1 & 1 & 1 & 1 & 1 & 1 & $\mathrm{X}$ & 0 & 1 \\
\hline Turkey & 1 & 1 & 1 & 1 & 0 & 0 & 1 & 0 & 1 & 1 & 1 & 0 & 1 & 0 & 0 & 1 & 0 & 1 & 0 & 0 & 1 & 1 & 1 & 0 & 1 & 1 & 1 & 0 & 0 & 1 & 0 & $\mathrm{X}$ & 1 \\
\hline United Kingdom & 1 & 1 & 1 & 1 & 1 & 1 & 1 & 1 & 1 & 1 & 1 & 1 & 1 & 1 & 1 & 1 & 1 & 1 & 1 & 1 & 1 & 1 & 1 & 1 & 1 & 1 & 1 & 1 & 1 & 1 & 1 & 1 & $\mathrm{X}$ \\
\hline
\end{tabular}


Table 4. Descriptive statistics for subsidiaries of European multinationals

Panel A: Number of parent companies and subsidiaries used in basic regression.

\begin{tabular}{|c|c|c|c|}
\hline \multirow[b]{2}{*}{ Country } & \multirow{2}{*}{$\begin{array}{c}\text { Number of parent companies } \\
\text { by home country }\end{array}$} & \multicolumn{2}{|c|}{ Number of subsidiaries } \\
\hline & & by home country & by host country \\
\hline Austria & 9 & 28 & 32 \\
\hline Belgium & 36 & 171 & 172 \\
\hline Bulgaria & 11 & 31 & 14 \\
\hline Croatia & 0 & 0 & 1 \\
\hline Cyprus & 0 & 0 & 0 \\
\hline Czech Republic & 0 & 2 & 7 \\
\hline Denmark & 28 & 224 & 309 \\
\hline Estonia & 6 & 8 & 2 \\
\hline Finland & 23 & 85 & 106 \\
\hline France & 116 & 274 & 152 \\
\hline Germany & 75 & 266 & 282 \\
\hline Greece & 48 & 135 & 46 \\
\hline Hungary & 0 & 2 & 10 \\
\hline Iceland & 3 & 11 & 12 \\
\hline Ireland & 11 & 18 & 46 \\
\hline Italy & 78 & 272 & 177 \\
\hline Latvia & 2 & 2 & 3 \\
\hline Lithuania & 0 & 0 & 1 \\
\hline Luxembourg & 1 & 1 & 4 \\
\hline Netherlands & 89 & 199 & 118 \\
\hline Norway & 45 & 77 & 202 \\
\hline Poland & 6 & 7 & 45 \\
\hline Portugal & 21 & 51 & 31 \\
\hline Romania & 0 & 0 & 37 \\
\hline Russia & 1 & 10 & 0 \\
\hline Slovak Republic & 1 & 2 & 0 \\
\hline Slovenia & 6 & 16 & 0 \\
\hline Spain & 56 & 350 & 432 \\
\hline Sweden & 76 & 224 & 218 \\
\hline Switzerland & 14 & 40 & 10 \\
\hline Turkey & 0 & 0 & 0 \\
\hline United Kingdom & 144 & 588 & 625 \\
\hline Total & 906 & 3,094 & 3,094 \\
\hline
\end{tabular}


Panel B: Summary statistics for variables in basic regression

\begin{tabular}{|c|c|c|c|c|c|}
\hline Variables & $\mathrm{N}$ & Mean & Standard dev. & Min & Max \\
\hline Subsidiary location & 26,567 & .034 & .182 & 0 & 1 \\
\hline Effective tax & 26,567 & .353 & .073 & .125 & .750 \\
\hline International tax & 26,567 & .051 & .071 & 0 & .550 \\
\hline Host country tax & 26,567 & .302 & .083 & 0 & .567 \\
\hline GDP bilateral & 26,567 & .033 & .054 & .0003 & .245 \\
\hline Contiguity & 26,567 & .148 & .355 & 0 & 1 \\
\hline Origin of law & 26,567 & .245 & .430 & 0 & 1 \\
\hline Difference in labor costs & 26,567 & -1.834 & 1.031 & -8.003 & .068 \\
\hline Economic freedom & 26,567 & 6.430 & 1.021 & 3.8 & 8.425 \\
\hline $\begin{array}{l}\text { EU membership } \\
\text { subsidiary }\end{array}$ & 26,567 & .464 & .499 & 0 & 1 \\
\hline
\end{tabular}

Panel C: Correlation matrix for variables in basic regression

\begin{tabular}{|c|c|c|c|c|c|c|c|c|c|}
\hline Location & Effective tax & $\begin{array}{l}\text { International } \\
\text { tax }\end{array}$ & $\begin{array}{c}\text { Host } \\
\text { country } \\
\text { corporate }\end{array}$ & $\begin{array}{c}\text { GDP } \\
\text { bilateral }\end{array}$ & Contiguity & $\begin{array}{l}\text { Origin of } \\
\text { law }\end{array}$ & $\begin{array}{l}\text { Difference } \\
\text { in labor } \\
\text { costs }\end{array}$ & $\begin{array}{l}\text { Economic } \\
\text { freedom }\end{array}$ & $\begin{array}{c}\text { EU } \\
\text { membership } \\
\text { subsidiary }\end{array}$ \\
\hline
\end{tabular}

\begin{tabular}{|c|c|c|c|c|c|c|c|c|c|c|}
\hline Subsidiary location & 1.0000 & & & & & & & & & \\
\hline Effective tax & -.0059 & 1.0000 & & & & & & & & \\
\hline International tax & $-.0801 * *$ & $.3375^{* *}$ & 1.0000 & & & & & & & \\
\hline Host country tax & $.0630 * *$ & $.5970 * *$ & $-.5537 * *$ & 1.0000 & & & & & & \\
\hline GDP bilateral & $.1672 * *$ & $.2656 * *$ & $-.2908 * *$ & $.4827 * *$ & 1.0000 & & & & & \\
\hline Contiguity & $.0734 * *$ & $0.0793 * *$ & $-.1099 * *$ & $.1639 * *$ & $.2323 * *$ & 1.0000 & & & & \\
\hline Origin of Law & -.0031 & $.0388 * *$ & $-.0151 *$ & $.0471 * *$ & $-.0213 * *$ & $.2551 * *$ & 1.0000 & & & \\
\hline $\begin{array}{l}\text { Difference in labor } \\
\text { costs }\end{array}$ & $-.0815 * *$ & $.0258 * *$ & $.1954 * *$ & $-.1437 * *$ & $-.1715^{* *}$ & $-.1842 * *$ & $-.1452 * *$ & 1.0000 & & \\
\hline Economic freedom & $.1032 * *$ & $-.1437 * *$ & $-.1661 * *$ & $.0144 * *$ & $.1942 * *$ & $.0791 * *$ & .0057 & $-.3124 * *$ & 1.0000 & \\
\hline $\begin{array}{l}\text { EU membership } \\
\text { subsidiary }\end{array}$ & $.1404 * *$ & $.0618 * *$ & $-.4992 * *$ & $.4801 * *$ & $.4975^{* *}$ & $.2093 * *$ & $.1111 * *$ & $-.4099 * *$ & $.4890 * *$ & 1.0000 \\
\hline $\begin{array}{l}\text { Note: Effective mar } \\
\text { source income into } \\
\text { International taxatio } \\
\text { in the foreign host c } \\
\text { a common border. } \\
\text { (1998). Difference } \\
\text { the following Fraser } \\
\text { taking the value } 1 \\
\text { significance at } 1 \% \text {. }\end{array}$ & $\begin{array}{l}\text { al tax rate } \\
\text { ount. Loca } \\
\text { s defined as } \\
\text { itry to the } \\
\text { gin of law } \\
\text { abor costs } i \\
\text { dicators fo } \\
\text { the subsidi }\end{array}$ & $\begin{array}{l}\text { s the statut } \\
\text { ation in su } \\
\text { difference } \\
\text { of GDP of } \\
\text { binary vari } \\
\text { log of the } \\
\text { subsidiary } \\
\text { country is }\end{array}$ & $\begin{array}{l}\text { x rate on } \\
\text { ary country } \\
\text { een the eff } \\
\text { her foreigr } \\
\text { taking the } \\
\text { lute value } \\
\text { try: a sour } \\
\text { ber of the }\end{array}$ & $\begin{array}{l}\text { end incom } \\
\text { he corpora } \\
\text { e margina } \\
\text { rnatives. } C \\
\text { e } 1 \text { if the } p \\
\text { e differen } \\
\text { gal system } \\
\text { opean Un }\end{array}$ & $\begin{array}{l}\text { erated in } t \\
\text { rate, incl } \\
\text { ate and th } \\
\text { uity is a b } \\
\text { and the } s \\
\text { abor costs } \\
\text { nce of tra } \\
\text { 3asic regr }\end{array}$ & $\begin{array}{l}\text { bsidiary cc } \\
\text { local taxe } \\
\text { l taxation } \\
\text { variable ta } \\
\text { iary count } \\
\text { nomic fre } \\
\text { rriers, and } \\
\text { refers to }\end{array}$ & $\begin{array}{l}\text { ry, taking } \\
\mathrm{d} \text { possible } \\
\text { he subsidia } \\
\mathrm{g} \text { the value } \\
\text { have a con } \\
\mathrm{n} \text { is an ind } \\
\text { ence of pri } \\
\text { gression } 1\end{array}$ & $\begin{array}{l}\text { lding taxe } \\
\text { arges appli } \\
\text { ntry. GDP } \\
\text { e parent a } \\
\text { origin of } 1 \\
\text { led betwee } \\
\text { trols. EU } \\
\text { able } 5 . *\end{array}$ & $\begin{array}{l}\text { the tax sy } \\
\text { in the su } \\
\text { eral is the } \\
\text { e subsidia } \\
\text { s defined } \\
\text { and } 10 \text { and } \\
\text { eership is } \\
\text { es signifi }\end{array}$ & $\begin{array}{l}\text { for foreign } \\
\text { y country } \\
\text { f the GDP } \\
\text { tries have } \\
\text { orta et al } \\
\text { average of } \\
\text { y variable } \\
\text { at } 5 \% \text {; * }\end{array}$ \\
\hline
\end{tabular}


Table 5. Taxation and foreign subsidiary location

The dependent variable is subsidiary location equaling 1 if a new subsidiary is located in a country and 0 otherwise. Effective tax is the tax rate on dividend income generated in the potential subsidiary country resulting from corporate income taxation in host and parent countries and non-resident withholding taxation in the host country. Host country corporate tax is the corporate income tax in the subsidiary country, including local taxes and possible surcharges. International taxation is the difference between the effective tax and the host country corporate tax. GDP bilateral is the ratio of the GDP in a potential host country to the sum of GDP of all potential host countries. Contiguity is a binary variable equal to 1 if the parent and potential host countries have a common border. Origin of law is a binary variable equal to 1 if the parent and potential host countries have a common origin of law as defined in La Porta et al. (1998). Difference in labor costs is the log of the absolute value of the difference in labor costs between parent and potential host countries. Economic freedom is an index scaled between 0 and 10 reflecting the following Fraser indicators of the potential host country: soundness of legal system, absence of trade barriers, and absence of price controls. EU membership is a binary equal to 1 if the potential host country is a member of the European Union. Sample reflects location decisions of new foreign subsidiaries. Estimation is by conditional fixed effects logit model. White (1980)'s heteroskedasticity-consistent standard errors are reported between brackets after clustering by corporate groups. Marginal effect is the slope of the probability curve with respect to an independent variable evaluated at mean values for all independent variables. Semi-elasticity is the associated semi-elasticity of the probability of subsidiary location with respect to an independent variable. $*$ denotes significance at $10 \% ; *$ significance at $5 \%$.

\begin{tabular}{|c|c|c|c|c|c|}
\hline $\begin{array}{l}\text { Variables (predicted sign of } \\
\text { coefficient) }\end{array}$ & $\begin{array}{c}(1) \\
\text { Basic regression }\end{array}$ & $\begin{array}{c}(2) \\
\text { Host country corporate } \\
\text { tax }\end{array}$ & $\begin{array}{c}\text { (3) } \\
\text { International tax }\end{array}$ & $\begin{array}{l}\text { (4) } \\
\text { Host country corporate } \\
\text { and international taxes }\end{array}$ & $\begin{array}{l}\text { (5) } \\
\text { Withholding and parent } \\
\text { country corporate taxes }\end{array}$ \\
\hline Effective tax ( - ) & $\begin{array}{c}-3.964 * * \\
(.555)\end{array}$ & & & & \\
\hline Host country corporate tax ( - ) & & $\begin{array}{c}-2.929 * * \\
(.425)\end{array}$ & & $\begin{array}{c}-3.928 * * \\
(.542)\end{array}$ & $\begin{array}{c}-4.274^{* *} \\
(.567)\end{array}$ \\
\hline International tax $(-)$ & & & $\begin{array}{c}-2.205^{* *} \\
(.858)\end{array}$ & $\begin{array}{l}-4.128 * * \\
(.963)\end{array}$ & \\
\hline Withholding tax ( - ) & & & & & $\begin{array}{l}-1.005 \\
(1.322)\end{array}$ \\
\hline Parent country corporate tax $(-)$ & & & & & $\begin{array}{c}-5.626 * * \\
(1.252)\end{array}$ \\
\hline GDP bilateral $(+)$ & $\begin{array}{l}7.449 * * \\
(.534)\end{array}$ & $\begin{array}{l}7.135^{* *} \\
(.509)\end{array}$ & $\begin{array}{l}5.471 * * \\
(.432)\end{array}$ & $\begin{array}{l}7.424 * * \\
(.529)\end{array}$ & $\begin{array}{l}7.616^{* *} \\
(.539)\end{array}$ \\
\hline Contiguity $(+)$ & $\begin{array}{l}.431 * * \\
(.082)\end{array}$ & $\begin{array}{l}.414 * * \\
(.082)\end{array}$ & $\begin{array}{l}.406 * * \\
(.082)\end{array}$ & $\begin{array}{l}.432 * * \\
(.082)\end{array}$ & $\begin{array}{l}.429 * * \\
(.081)\end{array}$ \\
\hline Origin of Law $(+/-)$ & $\begin{array}{l}-.116 \\
(.087)\end{array}$ & $\begin{array}{l}-.124 \\
(.086)\end{array}$ & $\begin{array}{l}-.148 \\
(.038)\end{array}$ & $\begin{array}{l}-.117 \\
(.087)\end{array}$ & $\begin{array}{l}-.084 \\
(.088)\end{array}$ \\
\hline Difference in labor costs ( - ) & $\begin{array}{r}-.159 * * \\
(.038)\end{array}$ & $\begin{array}{c}-.162 * * \\
(.038)\end{array}$ & $\begin{array}{c}-.169 * * \\
(.038)\end{array}$ & $\begin{array}{c}-.159 * * \\
(.038)\end{array}$ & $\begin{array}{c}-.161 * * \\
(.038)\end{array}$ \\
\hline Economic freedom $(+)$ & $\begin{array}{r}.288 * * \\
(.050)\end{array}$ & $\begin{array}{l}.304 * * \\
(.050)\end{array}$ & $\begin{array}{l}.403 * * \\
(.047)\end{array}$ & $\begin{array}{l}.290 * * \\
(.050)\end{array}$ & $\begin{array}{l}.301 * * \\
(.049)\end{array}$ \\
\hline EU membership subsidiary $(+)$ & $\begin{array}{r}.884 * * \\
(.110)\end{array}$ & $\begin{array}{c}.1 .107 * * \\
(.121)\end{array}$ & $\begin{array}{l}.724 * * \\
(.119)\end{array}$ & $\begin{array}{l}.870 * * \\
(.125)\end{array}$ & $\begin{array}{l}.970 * * \\
(.129)\end{array}$ \\
\hline
\end{tabular}




\begin{tabular}{|c|c|c|c|c|c|}
\hline $\begin{array}{l}\text { Variables (predicted sign of } \\
\text { coefficient) }\end{array}$ & $\begin{array}{c}\text { (1) } \\
\text { Basic regression }\end{array}$ & $\begin{array}{l}\text { (2) } \\
\text { Host country corporate } \\
\operatorname{tax} \\
\end{array}$ & $\begin{array}{c}(3) \\
\text { International tax }\end{array}$ & $\begin{array}{l}\text { (4) } \\
\text { Host country corporate } \\
\text { and international taxes }\end{array}$ & $\begin{array}{l}(5) \\
\text { Withholding and parent } \\
\text { country corporate taxes }\end{array}$ \\
\hline Number of observations & 26,567 & 26,567 & 26,567 & 26,567 & 26,567 \\
\hline Pseudo R-squared & .14 & .14 & .13 & .14 & .14 \\
\hline $\begin{array}{l}\text { Effective tax mean } \\
\text { Effective tax marginal effect } \\
\text { Effective tax semi-elasticity }\end{array}$ & $\begin{array}{c}.353 \\
-.615 * * \\
-.761 * *\end{array}$ & & & & \\
\hline $\begin{array}{l}\text { Host country corporate tax mean } \\
\text { Host country corporate tax } \\
\text { marginal effect }\end{array}$ & & $\begin{array}{c}.302 \\
-.274 * *\end{array}$ & & $\begin{array}{c}.302 \\
-.607 * *\end{array}$ & $\begin{array}{c}.302 \\
-.626^{* *}\end{array}$ \\
\hline $\begin{array}{l}\text { Host country corporate tax semi- } \\
\text { elasticity }\end{array}$ & & $-.306 * *$ & & $-.751 * *$ & $-.761 * *$ \\
\hline $\begin{array}{l}\text { International tax mean } \\
\text { International tax marginal effect } \\
\text { International tax semi-elasticity }\end{array}$ & & & $\begin{array}{l}.051 \\
-.074^{*} \\
-.076^{*}\end{array}$ & $\begin{array}{c}.051 \\
-.638 * * \\
-.789 * *\end{array}$ & \\
\hline $\begin{array}{l}\text { Withholding tax mean } \\
\text { Withholding tax marginal effect } \\
\text { Withholding tax semi-elasticity }\end{array}$ & & & & & $\begin{array}{l}.029 \\
-.147 \\
-.179\end{array}$ \\
\hline $\begin{array}{l}\text { Parent country corporate tax mean } \\
\text { Parent country corporate tax } \\
\text { marginal effect }\end{array}$ & & & & & $\begin{array}{c}.022 \\
-.823 * *\end{array}$ \\
\hline $\begin{array}{l}\text { Parent country corporate tax semi- } \\
\text { elasticity }\end{array}$ & & & & & $-1.002 * *$ \\
\hline
\end{tabular}


Table 6. Taxation and foreign subsidiary location: robustness tests

The dependent variable is subsidiary location equaling 1 if a new subsidiary is located in a country and 0 otherwise. Effective tax is the tax rate on dividend income generated in the potential subsidiary country resulting from corporate income taxation in host and parent countries and non-resident withholding taxation in the host country. Host country corporate tax is the corporate income tax in the subsidiary country, including local taxes and possible surcharges. Withholding tax is the withholding tax rate in a potential host country. Parent country corporate tax is the difference between effective tax and the sum of host country corporate tax and withholding tax. Contiguity is a binary variable equal to 1 if the parent and potential host countries have a common border. Origin of law is a binary variable equal to 1 if the parent and potential host countries have a common origin of law as defined in La Porta et al. (1998). Difference in labor costs is the log of the absolute value of the difference in labor costs between parent and potential host countries. Economic freedom is an index scaled between 0 and 10 reflecting the following Fraser indicators of the potential host country: soundness of legal system, absence of trade barriers, and absence of price controls. EU membership is a binary equal to 1 if the potential host country is a member of the European Union. Sample reflects location decisions of new foreign subsidiaries. Estimations of 1,4 and 5 are by the logit model, of 2 and 3 is by the linear probability model, and of 6 and 7 by is by the model proposed of Chamberlain. White (1980)'s heteroskedasticity-consistent standard errors are reported between brackets after clustering by corporate groups. Marginal effect is the slope of the probability curve with respect to an independent variable evaluated at mean values for all independent variables. Semi-elasticity is the associated semi-elasticity of the probability of subsidiary location with respect to an independent variable. * denotes significance at $10 \%$; ** significance at $5 \%$.

\begin{tabular}{|c|c|c|c|c|c|c|c|}
\hline Variable (predicted sign of coefficient) & $\begin{array}{c}(1) \\
\text { Domestic } \\
\text { country option }\end{array}$ & $\begin{array}{c}(2) \\
\text { Linear } \\
\text { probability with } \\
\text { bilateral } \\
\text { dummies } \\
\end{array}$ & $\begin{array}{c}(3) \\
\text { Linear } \\
\text { probability with } \\
\text { bilateral } \\
\text { dummies } \\
\end{array}$ & $\begin{array}{c}\text { (4) } \\
\text { Basic regression } \\
\text { with multiple } \\
\text { positive values }\end{array}$ & $\begin{array}{l}\text { (5) } \\
\text { Split taxes with } \\
\text { multiple } \\
\text { positive values }\end{array}$ & $\begin{array}{c}(6) \\
\text { Chamberlain }\end{array}$ & $\begin{array}{c}\text { (7) } \\
\text { Chamberlain } \\
\text { Split taxes }\end{array}$ \\
\hline Effective tax (-) & $\begin{array}{c}-1.465 * * \\
(.406)\end{array}$ & $\begin{array}{l}-.098^{*} \\
(.042)\end{array}$ & & $\begin{array}{c}-4.001 * * \\
(.557)\end{array}$ & & $\begin{array}{c}-3.618^{* *} \\
(.483)\end{array}$ & \\
\hline Host country corporate tax $(-)$ & & & $\begin{array}{l}-.109 * \\
(.045)\end{array}$ & & $\begin{array}{c}-4.329 * * \\
(.571)\end{array}$ & & $\begin{array}{c}-3.254 * * \\
(.466)\end{array}$ \\
\hline Withholding tax ( - ) & & & $\begin{array}{l}-.049 \\
(.058)\end{array}$ & & $\begin{array}{c}-.993 \\
(1.343)\end{array}$ & & $\begin{array}{c}-3.402 * * \\
(.096)\end{array}$ \\
\hline Parent country corporate tax $(-)$ & & & $\begin{array}{l}-.070 \\
(.039)\end{array}$ & & $\begin{array}{c}-5.655^{* *} \\
(1.127)\end{array}$ & & $\begin{array}{c}-5.415 * * \\
(.951)\end{array}$ \\
\hline GDP bilateral $(+)$ & $\begin{array}{c}5.113 * * \\
(.418)\end{array}$ & $\begin{array}{l}-.780 \\
(.774)\end{array}$ & $\begin{array}{l}-.743 \\
(.777)\end{array}$ & $\begin{array}{c}7.540 * * \\
(.540)\end{array}$ & $\begin{array}{c}7.716^{* *} \\
(.546)\end{array}$ & $\begin{array}{c}6.605 * * \\
(.428)\end{array}$ & $\begin{array}{c}6.387 * * \\
(.426)\end{array}$ \\
\hline Contiguity $(+)$ & $\begin{array}{c}1.062 * * \\
(.060)\end{array}$ & & & $\begin{array}{c}0.439 * * \\
(.826)\end{array}$ & $\begin{array}{l}.436 * * \\
(.083)\end{array}$ & $\begin{array}{l}.435^{* *} \\
(.068)\end{array}$ & $\begin{array}{l}.441 * * \\
(.068)\end{array}$ \\
\hline Origin of Law $(+/-)$ & $\begin{array}{l}.419 * * \\
(.055)\end{array}$ & & & $\begin{array}{l}-.120 \\
(.087)\end{array}$ & $\begin{array}{l}-.087 \\
(.088)\end{array}$ & $\begin{array}{l}.185^{* *} \\
(.074)\end{array}$ & $\begin{array}{l}.185^{* *} \\
(.074)\end{array}$ \\
\hline Difference in labor costs $(-)$ & $\begin{array}{l}.528 * * \\
(.025)\end{array}$ & $\begin{array}{l}-.001 \\
(.003)\end{array}$ & $\begin{array}{l}-.001 \\
(.003)\end{array}$ & $\begin{array}{c}-.160 * * \\
(.038)\end{array}$ & $\begin{array}{c}-.161 * * \\
(.038)\end{array}$ & $\begin{array}{c}-.136^{* * *} \\
(.024)\end{array}$ & $\begin{array}{c}-.131^{* *} \\
(.023)\end{array}$ \\
\hline Economic freedom $(+)$ & $\begin{array}{l}.279 * * \\
(.039)\end{array}$ & $\begin{array}{l}-.004 \\
(.003)\end{array}$ & $\begin{array}{l}-.004 \\
(.003)\end{array}$ & $\begin{array}{l}.290 * * \\
(.050)\end{array}$ & $\begin{array}{l}.303 * * \\
(.049)\end{array}$ & $\begin{array}{l}.229 * * \\
(.039)\end{array}$ & $\begin{array}{l}.246^{* *} \\
(.039)\end{array}$ \\
\hline EU membership subsidiary $(+)$ & $\begin{array}{c}1.669^{* *} \\
(.100)\end{array}$ & & & $\begin{array}{l}.884 * * \\
(.111)\end{array}$ & $\begin{array}{l}.975 * * \\
(.131)\end{array}$ & $\begin{array}{c}1.108 * * \\
(.092)\end{array}$ & $\begin{array}{l}.970 * * \\
(.101)\end{array}$ \\
\hline Constant & & .040 & .045 & & & & \\
\hline
\end{tabular}




\begin{tabular}{|c|c|c|c|c|c|c|c|}
\hline Variable (predicted sign of coefficient) & $\begin{array}{c}(1) \\
\text { Domestic } \\
\text { country option }\end{array}$ & $\begin{array}{c}(2) \\
\text { Linear } \\
\text { probability with } \\
\text { bilateral } \\
\text { dummies } \\
\end{array}$ & $\begin{array}{c}(3) \\
\text { Linear } \\
\text { probability with } \\
\text { bilateral } \\
\text { dummies } \\
\end{array}$ & $\begin{array}{c}\text { (4) } \\
\text { Basic regression } \\
\text { with multiple } \\
\text { positive values }\end{array}$ & $\begin{array}{l}\text { (5) } \\
\text { Split taxes with } \\
\text { multiple } \\
\text { positive values }\end{array}$ & $\begin{array}{c}\text { (6) } \\
\text { Chamberlain }\end{array}$ & $\begin{array}{c}\text { (7) } \\
\text { Chamberlain } \\
\text { Split taxes }\end{array}$ \\
\hline & & $(.032)$ & $(.033)$ & & & & \\
\hline Number of observations & 51,061 & 26,945 & 26,945 & 25,024 & 25,024 & 163,222 & 161,575 \\
\hline Pseudo R-squared & .30 & .18 & .18 & .14 & .14 & .11 & .11 \\
\hline Sample mean Effective tax & .353 & & & .353 & & .342 & \\
\hline Marginal effect Effective tax & $-.201 * *$ & & & $-.620 * *$ & & $-.633 * *$ & \\
\hline Semi-elasticity Effective tax & $-.241 * *$ & & & $-.767 * *$ & & $-.818 * *$ & \\
\hline Sample mean host country tax & & & & & .302 & & .291 \\
\hline Marginal effect host country tax & & & & & $-.633 * *$ & & $-.552 * *$ \\
\hline Semi-elasticity host country tax & & & & & $-.770 * *$ & & $-.704 * *$ \\
\hline Sample mean withholding tax & & & & & .029 & & .009 \\
\hline Marginal effect withholding tax & & & & & -.145 & & $-.577 * *$ \\
\hline Semi-elasticity withholding tax & & & & & -.177 & & $-.736 * *$ \\
\hline Sample mean parent country tax & & & & & .023 & & .041 \\
\hline Marginal effect parent country tax & & & & & $-.827 * *$ & & $-.918 * *$ \\
\hline Semi-elasticity parent country tax & & & & & $-1.006 * *$ & & $-1.171 * *$ \\
\hline Prediction (prob location) & .835 & & & .808 & .822 & .774 & .784 \\
\hline
\end{tabular}


Table 7. Tax sensitivity of foreign subsidiary location and the number of new subsidiaries

The dependent variable is subsidiary location equaling 1 if a new subsidiary is located in a country and 0 otherwise. Effective tax is the tax rate on dividend income generated in the potential subsidiary country resulting from corporate income taxation in host and parent countries and non-resident withholding taxation in the host country. Host country corporate tax is the corporate income tax in the subsidiary country, including local taxes and possible surcharges. Withholding tax is the withholding tax rate in a potential host country. Parent country corporate tax is the difference between effective tax and the sum of host country corporate tax and withholding tax. Contiguity is a binary variable equal to 1 if the parent and potential host countries have a common border. Origin of law is a binary variable equal to 1 if the parent and potential host countries have a common origin of law as defined in La Porta et al. (1998). Difference in labor costs is the log of the absolute value of the difference in labor costs between parent and potential host countries. Economic freedom is an index scaled between 0 and 10 reflecting the following Fraser indicators of the potential host country: soundness of legal system, absence of trade barriers, and absence of price controls. EU membership is a binary equal to 1 if the potential host country is a member of the European Union. Sample reflects location decisions of new foreign subsidiaries. Estimation is by the conditional fixed effects logit model. Regression 1 restricts the sample to observations where multinational firms resident in France, Germany or the United Kingdom establish a new foreign subsidiary in one other two countries. Regression 2, 3 , and 4 restrict the sample to observations where multinational firms establish 1, 2 or 3 new foreign subsidiaries during the sample period. Regression 5 includes interaction variables of the effective tax rate with dummy variables signaling that the multinational establishes $1,2,34$, 5, or more than 5 new foreign subsidiaries. White (1980)'s heteroskedasticity-consistent standard errors are reported between brackets after clustering by corporate groups. Marginal effect is the slope of the probability curve with respect to an independent variable evaluated at mean values for all independent variables. Semi-elasticity is the associated semi-elasticity of the probability of subsidiary location with respect to an independent variable. The goodness of fit is the percentage of correct predictions (either fitted value of location $>0.5$ and actual location $=1$ or fitted value of location $=<0$ and actual location $=0)$. * denotes significance at $10 \%$; ** significance at $5 \%$.

\begin{tabular}{|c|c|c|c|c|c|}
\hline $\begin{array}{l}\text { Variables (predicted sign of } \\
\text { coefficient) }\end{array}$ & $\begin{array}{c}\text { (1) } \\
\text { France, Germany, } \\
\text { and UK }\end{array}$ & $\begin{array}{c}(2) \\
\text { One new subsidiary }\end{array}$ & $\begin{array}{c}(3) \\
\text { Two new } \\
\text { subsidiaries }\end{array}$ & $\begin{array}{c}\text { (4) } \\
\text { Three new } \\
\text { subsidiaries }\end{array}$ & $\begin{array}{l}\text { (5) } \\
\text { Interactions with the } \\
\text { number of existing } \\
\text { foreign subsidiaries }\end{array}$ \\
\hline Effective tax ( - ) & $\begin{array}{c}-11.633^{* *} \\
(1.886)\end{array}$ & $\begin{array}{c}-3.517 * * \\
(.593)\end{array}$ & $\begin{array}{c}-6.924 * * \\
(1.730)\end{array}$ & $\begin{array}{l}-4.692 * * \\
(2.375)\end{array}$ & \\
\hline Effective tax interacted $1 \mathrm{sub}(-)$ & & & & & $\begin{array}{c}-4.433 * * \\
(.867)\end{array}$ \\
\hline Effective tax interacted 2 subs $(-)$ & & & & & $\begin{array}{c}-3.726^{* *} \\
(1.080)\end{array}$ \\
\hline Effective tax interacted 3 subs $(-)$ & & & & & $\begin{array}{l}-3.172 * * \\
(1.301)\end{array}$ \\
\hline Effective tax interacted 4 subs ( - ) & & & & & $\begin{array}{c}-5.028 * * \\
(1.479)\end{array}$ \\
\hline Effective tax interacted 5 subs $(-)$ & & & & & $\begin{array}{c}-4.177 * * \\
(1.960)\end{array}$ \\
\hline $\begin{array}{l}\text { Effective tax interacted more than } \\
5 \text { subs }(-)\end{array}$ & & & & & $\begin{array}{c}-3.591 * * \\
(.834)\end{array}$ \\
\hline GDP bilateral $(+)$ & $\begin{array}{c}26.182 * * \\
(5.061)\end{array}$ & $\begin{array}{c}7.438 * * \\
(.589)\end{array}$ & $\begin{array}{c}7.772 * * \\
(1.528)\end{array}$ & $\begin{array}{l}7.470 * * \\
(2.335)\end{array}$ & $\begin{array}{c}7.441 * * \\
(.534)\end{array}$ \\
\hline Contiguity $(+)$ & $\begin{array}{l}.853 * * \\
(238)\end{array}$ & $\begin{array}{l}.420 * * \\
(.091)\end{array}$ & $\begin{array}{l}.656^{* *} \\
(.226)\end{array}$ & $\begin{array}{l}.164 \\
(.335)\end{array}$ & $\begin{array}{l}.430 * * \\
(.082)\end{array}$ \\
\hline
\end{tabular}




\begin{tabular}{|c|c|c|c|c|c|}
\hline $\begin{array}{l}\text { Variables (predicted sign of } \\
\text { coefficient) }\end{array}$ & $\begin{array}{l}\text { (1) } \\
\text { France, Germany, } \\
\text { and UK }\end{array}$ & $\begin{array}{c}(2) \\
\text { One new subsidiary }\end{array}$ & $\begin{array}{c}\text { (3) } \\
\text { Two new } \\
\text { subsidiaries }\end{array}$ & $\begin{array}{c}\text { (4) } \\
\text { Three new } \\
\text { subsidiaries }\end{array}$ & $\begin{array}{l}\text { (5) } \\
\text { Interactions with the } \\
\text { number of existing } \\
\text { foreign subsidiaries }\end{array}$ \\
\hline Origin of Law $(+/-)$ & $\begin{array}{l}-.023 \\
(.378)\end{array}$ & $\begin{array}{l}-.135 \\
(.096)\end{array}$ & $\begin{array}{l}-.050 \\
(.242)\end{array}$ & $\begin{array}{l}-.027 \\
(.399)\end{array}$ & $\begin{array}{l}-.116 \\
(.087)\end{array}$ \\
\hline Diff Labor costs ( - ) & $\begin{array}{l}-.022 \\
(.132)\end{array}$ & $\begin{array}{r}-.159^{* *} \\
(.042)\end{array}$ & $\begin{array}{l}-.105 \\
(.120)\end{array}$ & $\begin{array}{l}-.299 \\
(.163)\end{array}$ & $\begin{array}{c}-.160 * * \\
(.038)\end{array}$ \\
\hline Economic Freedom $(+)$ & $\begin{array}{l}.810^{* * *} \\
(.212)\end{array}$ & $\begin{array}{r}.329 * * \\
(.054)\end{array}$ & $\begin{array}{l}.063 \\
(.157)\end{array}$ & $\begin{array}{l}.169 \\
(.234)\end{array}$ & $\begin{array}{l}.288 * * \\
(.050)\end{array}$ \\
\hline EU Membership subsidiary $(+)$ & & $\begin{array}{r}.763 * * \\
(.118)\end{array}$ & $\begin{array}{c}1.482 * * \\
(.355)\end{array}$ & $\begin{array}{c}1.436^{* *} \\
(.598)\end{array}$ & $\begin{array}{l}.882 * * \\
(.110)\end{array}$ \\
\hline Number of observations & 735 & 21,612 & 3,382 & 1,391 & 26,567 \\
\hline Pseudo R-squared & .18 & .13 & .17 & .17 & .14 \\
\hline Goodness-of-fit & .728 & .966 & .966 & .966 & .966 \\
\hline $\begin{array}{l}\text { Sample mean Effective tax } \\
\text { Marginal effect Effective tax } \\
\text { Semi-elasticity Effective tax }\end{array}$ & $\begin{array}{l}.383 \\
-.020 \\
-.020\end{array}$ & $\begin{array}{c}.355 \\
-.430 * * \\
-.502 *\end{array}$ & $\begin{array}{c}.344 \\
-1.504^{* *} \\
-4.715^{*}\end{array}$ & $\begin{array}{l}.355 \\
-.952 \\
-1.328\end{array}$ & \\
\hline
\end{tabular}


Table 8. Tax sensitivity of foreign subsidiary location and the number of foreign countries

The dependent variable is subsidiary location equaling 1 if a new is located in a country and 0 otherwise with data only for 1999. Effective tax is the tax rate on dividend income generated in the potential subsidiary country resulting from corporate income taxation in host and parent countries and non-resident withholding taxation in the host country. Host country corporate tax is the corporate income tax in the subsidiary country, including local taxes and possible surcharges. Withholding tax is the withholding tax rate in a potential host country. Parent country corporate tax is the difference between effective tax and the sum of host country corporate tax and withholding tax. Contiguity is a binary variable equal to 1 if the parent and potential host countries have a common border. Origin of law is a binary variable equal to 1 if the parent and potential host countries have a common origin of law as defined in La Porta et al. (1998). Difference in labor costs is the log of the absolute value of the difference in labor costs between parent and potential host countries. Economic freedom is an index scaled between 0 and 10 reflecting the following Fraser indicators of the potential host country: soundness of legal system, absence of trade barriers, and absence of price controls. EU membership is a binary equal to 1 if the potential host country is a member of the European Union. Sample reflects location decisions of new foreign subsidiaries. Estimation is by the conditional fixed effects logit model. Regressions 1, 2,3, 4 and 5 restrict the sample to observations where multinational firms have foreign subsidiaries in $1,2,3,4$, and 5 countries. Regression 6 includes interaction variables of the effective tax rate with dummy variables signaling that the multinational has foreign subsidiaries in 1,2, 3, 4, 5, or more than 5 countries. White (1980)'s heteroskedasticityconsistent standard errors are reported between brackets after clustering by corporate groups. Marginal effect is the slope of the probability curve with respect to an independent variable evaluated at mean values for all independent variables. Semi-elasticity is the associated semi-elasticity of the probability of subsidiary location with respect to an independent variable. The goodness of fit is the percentage of correct predictions (either fitted value of location $>0.5$ and actual location=1 or fitted value of location $=<0$ and actual location $=0$ ). * denotes significance at $10 \% ; * *$ significance at $5 \%$.

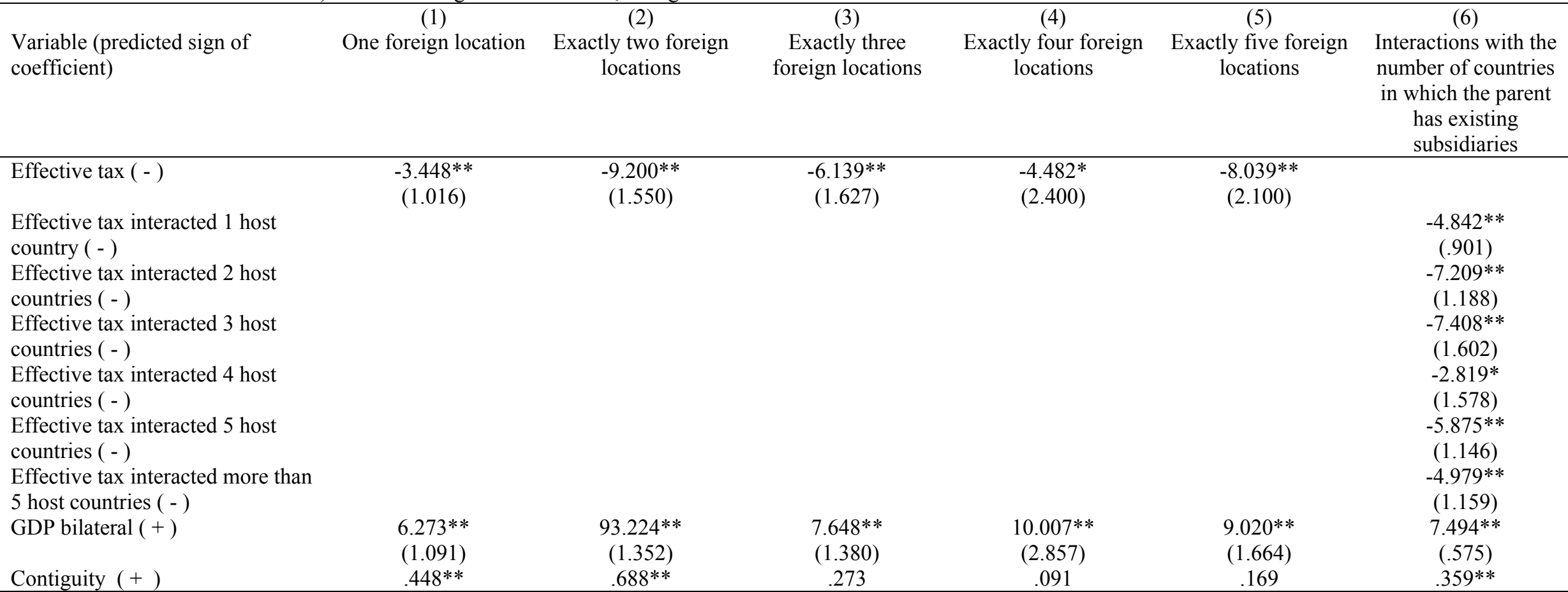


(4)

Exactly four foreign Exactly five foreign locations

(5) locations
(2)

One foreign location $\begin{gathered}\text { Exactly two foreign } \\ \text { locations }\end{gathered}$
One foreign location
locations
(3)

Exactly three foreign locations
Variable (predicted sign of coefficient)

Interactions with the number of countries in which the parent

has existing subsidiaries

\begin{tabular}{|c|c|c|c|c|c|c|}
\hline & & & & & & \\
\hline \multirow{3}{*}{ Origin of Law $(+/-)$} & $(.146)$ & $(.188)$ & $(.277)$ & $(.365)$ & $(.268)$ & $(.084)$ \\
\hline & .167 & .180 & .061 & .343 & $.692 * *$ & $.180 * *$ \\
\hline & $(.157)$ & $(.204)$ & $(.225)$ & $(.390)$ & $(.231)$ & $(.091)$ \\
\hline \multirow[t]{2}{*}{ Difference in labor costs ( - ) } & $-.221 * *$ & -.102 & -.118 & -.126 & .005 & $-.085 * *$ \\
\hline & $(.072)$ & $(.092)$ & $(.103)$ & $(.136)$ & $(.167)$ & $(.041)$ \\
\hline \multirow[t]{2}{*}{ Economic freedom $(+)$} & $.310^{* *}$ & -.082 & $.336^{*}$ & -.115 & -.076 & .093 \\
\hline & $(.102)$ & $(.135)$ & $(.181)$ & $(.117)$ & $(.211)$ & $(.058)$ \\
\hline \multirow[t]{2}{*}{ EU membership subsidiary $(+)$} & $.807 * *$ & $1.040 * *$ & $.645 * *$ & $1.328 * *$ & $1.432 * *$ & $1.139 * *$ \\
\hline & $(.208)$ & $(.296)$ & $(.328)$ & $(.558)$ & $(.292)$ & $(.131)$ \\
\hline Number of observations & 6,947 & 4,698 & 3,405 & 1,836 & 2,025 & 23,285 \\
\hline Pseudo R-squared & .13 & .14 & .10 & .12 & .11 & .11 \\
\hline Goodness-of-fit & .963 & .963 & .965 & .965 & .964 & .964 \\
\hline Sample mean Effective tax & .378 & .369 & .370 & .356 & .352 & \\
\hline Marginal effect Effective tax & -.398 & -.510 & -1.309 & $-.865 * *$ & -.758 & \\
\hline Semi-elasticity Effective tax & -.459 & $-8.658 * *$ & -1.890 & -3.311 & $-7.193 * *$ & \\
\hline
\end{tabular}




\section{Table 9. Taxation and parent firm location}

The dependent variable is choice of location of the parent for each pair of companies. It is equal to 1 if the corporate choice (the pair parent-subsidiary) is the actual choice and 0 otherwise. Each regression uses a logit model without a constant. All regressions use the tax on sales of companies as a proxy for profit and include country dummies that take the value 1 if the parent is located in this country, -1 if the subsidiary is located in this country and 0 otherwise. In regression 1 , the difference in effective tax liability is the difference between the effective tax burden paid by the group on its total profit between the 2 choices of location for the parent. This difference can be split into differences due to withholding taxation and differences due to the parent country treatment of the repatriated profit. Those are reflected in regressions 2 to 4 . The relative corporate tax is the statutory tax rate of the parent company minus the statutory tax rate of the subsidiary divided by the sum of these two tax rates. The relative size of assets is total assets of the parent company minus the total assets of the subsidiary divided by their sum. The relative size of sales is the sales of the parent company minus the sales of the subsidiary divided by their sum. The relative GDP is the GDP of the parent's country minus the GDP of the subsidiary country divided by their sum. The relative GDP per capita is the GDP per capita of the parent's country minus the GDP per capita of the subsidiary country divided by their sum. The relative financial development is sum of the domestic credit and market capitalization in percentage of GDP of the parent's country minus the sum of the domestic credit and market capitalization in percentage of GDP of the subsidiary's country divided by their sum. We report White (1980)'s heteroskedasticity-consistent standard errors between brackets after clustering by corporate groups. The semi-elasticity indicates the change in the probability to locate abroad (in percent) following an increase in the tax variable by 1 percentage point, given the independent variables and holding all other variables constant (in this case at their mean value). They are computed as the probability of a positive outcome. Marginal effect is the slope of the probability curve relating the independent variable to the probability of the dependent variable to take the value 1, given the independent variables and holding all other variables constant (in this case at their mean value). It shows the change in the probability to locate abroad (in percentage point) following an increase of the tax variable by 1 percentage point. The goodness of fit is the percentage of correct predictions (with either prediction of location $>0.5$ and actual location $=1$ or prediction of location $=<0$ and actual location $=0) . *$ denotes significance at $10 \%$; $* *$ significance at $5 \%$.

\begin{tabular}{|c|c|c|c|c|c|}
\hline & $\begin{array}{l}(1) \\
\text { Effective tax } \\
\text { rate }\end{array}$ & $\begin{array}{c}(2) \\
\text { Split taxes }\end{array}$ & $\begin{array}{c}(3) \\
\text { Parent tax only }\end{array}$ & $\begin{array}{l}\text { (4) } \\
\text { Withholding tax } \\
\text { only }\end{array}$ & $\begin{array}{l}\text { (5) } \\
\text { Corporate tax } \\
\text { rate only }\end{array}$ \\
\hline \multicolumn{6}{|l|}{ Tax variables } \\
\hline Relative effective tax liability & $\begin{array}{c}-11.556^{* *} \\
(5.745)\end{array}$ & & & & \\
\hline Relative withholding tax liability & & $\begin{array}{c}-2.693 \\
(14.618)\end{array}$ & & $\begin{array}{l}-13.089 \\
(12.614)\end{array}$ & \\
\hline Relative parent country tax liability & & $\begin{array}{c}-19.811 \\
(13.011)\end{array}$ & $\begin{array}{c}-21.190 * * \\
(10.021)\end{array}$ & & \\
\hline Relative corporate tax rate & $\begin{array}{c}-89.458 \\
(61.361)\end{array}$ & $\begin{array}{c}-90.132 \\
(63.563)\end{array}$ & $\begin{array}{c}-90.833 \\
(64.637)\end{array}$ & $\begin{array}{c}-93.410 \\
(58.928)\end{array}$ & $\begin{array}{c}-98.311 \\
(61.297)\end{array}$ \\
\hline \multicolumn{6}{|l|}{ Control variables } \\
\hline Relative assets & $\begin{array}{l}.226 \\
(.273)\end{array}$ & $\begin{array}{l}.209 \\
(.272)\end{array}$ & $\begin{array}{l}.205 \\
(.272)\end{array}$ & $\begin{array}{c}.243 \\
(.274)\end{array}$ & $\begin{array}{l}.231 \\
(.274)\end{array}$ \\
\hline Relative sales & $\begin{array}{c}-.578^{* *} \\
(.277)\end{array}$ & $\begin{array}{c}-.586^{* *} \\
(.276)\end{array}$ & $\begin{array}{c}-.582 * * \\
(.276)\end{array}$ & $\begin{array}{l}-.524^{*} \\
(.275)\end{array}$ & $\begin{array}{l}-.471 * \\
(.271)\end{array}$ \\
\hline Relative GDP & $\begin{array}{c}-1.820 \\
(1.857)\end{array}$ & $\begin{array}{c}-2.069 \\
(1.845)\end{array}$ & $\begin{array}{c}-2.126 \\
(1.864)\end{array}$ & $\begin{array}{l}-1.605 \\
(1.844)\end{array}$ & $\begin{array}{c}-1.831 \\
(1.892)\end{array}$ \\
\hline Relative GDP per capita & $\begin{array}{c}11.773 \\
(10.681)\end{array}$ & $\begin{array}{c}12.740 \\
(10.678)\end{array}$ & $\begin{array}{c}12.758 \\
(10.708)\end{array}$ & $\begin{array}{c}9.039 \\
(11.459)\end{array}$ & $\begin{array}{c}7.401 \\
(12.596)\end{array}$ \\
\hline Relative stock market development & $\begin{array}{c}-.964 \\
(1.780)\end{array}$ & $\begin{array}{c}-.977 \\
(1.793)\end{array}$ & $\begin{array}{l}-1.000 \\
(1.802)\end{array}$ & $\begin{array}{l}-1.127 \\
(1.764)\end{array}$ & $\begin{array}{l}-1.381 \\
(1.810)\end{array}$ \\
\hline
\end{tabular}


(1)

Effective tax

(2)

Split taxes

Number of observations

Number of corporate groups

Log-Likelihood

Goodness-of-fit

Sample mean of relative effective tax liability

Marginal effect relative effective tax liability

Semi-elasticity relative effective tax liability

Sample mean of relative withholding tax liability

Marginal effect relative withholding tax liability

Semi-elasticity relative withholding tax liability

Sample mean of relative parent country tax liability

Marginal effect of relative parent country tax liability

Semi-elasticity of relative parent county tax liability

Sample mean of relative corporate tax

Marginal effect relative corporate tax

Semi-elasticity relative corporate tax

$756 \quad 756$

$653 \quad 653$

$-382.035$

.743

$-381.687$

743

.001

$-2.256^{* *}$

$-3.074 * *$
(3)

(4)

(5)

Parent tax only

Withholding tax only

Corporate tax

\begin{tabular}{lcccc} 
& .000 & & .000 & \\
& -.525 & & -2.569 & \\
& -.715 & & -3.510 & \\
& & & & \\
& .000 & .000 & & \\
& -3.863 & $-4.132^{* *}$ & & -.006 \\
-.006 & -5.259 & $-5.625^{* *}$ & & $-19.366^{*}$ \\
-17.466 & & & & $-26.520^{*}$ \\
-23.795 & -.006 & -.006 & -.006 & \\
\hline
\end{tabular}




\section{Appendix. Variable definitions and data sources}

\begin{tabular}{|c|c|c|}
\hline Variable & Definition & Source \\
\hline Location of subsidiary & $\begin{array}{l}\text { Dummy variable equal to one if foreign subsidiary is located in a country } \\
\text { and zero otherwise }\end{array}$ & Amadeus database (Bureau Van Dijk) \\
\hline Location of parent & $\begin{array}{l}\text { Dummy variable equal to one if parent firm is located in a country and } \\
\text { zero otherwise }\end{array}$ & Amadeus database (Bureau Van Dijk) \\
\hline Effective tax & $\begin{array}{l}\text { Combined, bilateral tax on the subsidiary's income if repatriated in the } \\
\text { form of dividends as a share of the subsidiary's pre-tax income }\end{array}$ & $\begin{array}{l}\text { International Bureau of Fiscal Documentation } \\
\text { and various ministries }\end{array}$ \\
\hline International tax & $\begin{array}{l}\text { Sum of withholding tax and parent country corporate income tax as a share } \\
\text { of the subsidiary's pre-tax income }\end{array}$ & $\begin{array}{l}\text { International Bureau of Fiscal Documentation } \\
\text { and various ministries }\end{array}$ \\
\hline Parent country corporate tax & $\begin{array}{l}\text { Residual parent tax calculated as the difference between the effective tax } \\
\text { and the sum of the host country corporate income tax and the withholding } \\
\text { tax, as a share of the subsidiary's pre-tax income }\end{array}$ & $\begin{array}{l}\text { International Bureau of Fiscal Documentation } \\
\text { and various ministries }\end{array}$ \\
\hline GDP bilateral & $\begin{array}{l}\text { Ratio of the GDP of the host country to the sum of GDP of all possible } \\
\text { foreign locations. }\end{array}$ & Ameco database (European Commission) \\
\hline Contiguity & $\begin{array}{l}\text { Binary variable taking the value } 1 \text { if the parent and the subsidiary countries } \\
\text { have a common border }\end{array}$ & Authors' calculation \\
\hline Origin of law & $\begin{array}{l}\text { Binary variable taking the value } 1 \text { if the parent and the subsidiary countries } \\
\text { have a common origin of law }\end{array}$ & La Porta et al. (1998) \\
\hline Difference labor costs & $\begin{array}{l}\text { Log of the difference in labor costs (Labor compensation per unit of output } \\
\text { in USD 1990). }\end{array}$ & OECD \\
\hline Economic Freedom & $\begin{array}{l}\text { Time-varying index scaled between } 0 \text { and } 10 \text { and is an average of the } \\
\text { following Fraser indicators for the subsidiary country: a sound legal system } \\
\text { (A trusted legal framework exists for private businesses to challenge the } \\
\text { legality of government actions or regulation), transfer and subsidies in \% of } \\
\text { GDP, absence of regulatory trade barriers, and absence of price controls } \\
\text { (extent to which businesses are free to set their own prices) }\end{array}$ & $\begin{array}{l}\text { Fraser Institute - Economic Freedom of the } \\
\text { World Index }\end{array}$ \\
\hline EU membership subsidiary & $\begin{array}{l}\text { EU membership subsidiary s a binary variable taking the value } 1 \text { if the } \\
\text { subsidiary country is member of the European Union }\end{array}$ & Authors' calculation \\
\hline Relative effective tax liability & $\begin{array}{l}\text { Difference of total tax liability of multinational firm on assumption of } \\
\text { parent firm location in any two countries divided by total multinational firm } \\
\text { assets }\end{array}$ & $\begin{array}{l}\text { Amadeus database (Bureau Van Dijk)and } \\
\text { International Bureau of Fiscal Documentation } \\
\text { and various ministries }\end{array}$ \\
\hline $\begin{array}{l}\text { Relative withholding tax } \\
\text { liability }\end{array}$ & $\begin{array}{l}\text { Difference of withholding tax liability of multinational firm on assumption } \\
\text { of parent firm location in any two countries divided by total multinational } \\
\text { firm assets }\end{array}$ & $\begin{array}{l}\text { Amadeus database (Bureau Van Dijk)and } \\
\text { International Bureau of Fiscal Documentation } \\
\text { and various ministries }\end{array}$ \\
\hline
\end{tabular}




\begin{tabular}{|c|c|c|}
\hline Variable & Definition & Source \\
\hline $\begin{array}{l}\text { Relative parent country tax } \\
\text { liability }\end{array}$ & $\begin{array}{l}\text { Difference of parent country tax liability of multinational firm on } \\
\text { assumption of parent firm location in any two countries divided by total } \\
\text { multinational firm assets }\end{array}$ & $\begin{array}{l}\text { Amadeus database (Bureau Van Dijk)and } \\
\text { International Bureau of Fiscal Documentation } \\
\text { and various ministries }\end{array}$ \\
\hline Relative corporate tax rate & $\begin{array}{l}\text { Corporate tax rate in a country divided by sum of corporate tax rates in all } \\
\text { countries of establishment of multinational firm }\end{array}$ & $\begin{array}{l}\text { Amadeus and International Bureau of Fiscal } \\
\text { Documentation and various ministries }\end{array}$ \\
\hline Relative assets & $\begin{array}{l}\text { Assets in a country divided by sum of assets in all countries of } \\
\text { establishment of multinational firm }\end{array}$ & Amadeus database (Bureau Van Dijk) \\
\hline Relative sales & $\begin{array}{l}\text { Sales in a country divided by sum of sales in all countries of establishment } \\
\text { of multinational firm }\end{array}$ & Amadeus database (Bureau Van Dijk) \\
\hline Relative GDP & $\begin{array}{l}\text { GDP in a country divided by sum of GDPs in all countries of establishment } \\
\text { of multinational firm }\end{array}$ & $\begin{array}{l}\text { Amadeus database (Bureau Van Dijk) and } \\
\text { Ameco database (European Commission) }\end{array}$ \\
\hline Relative GDP per capita & $\begin{array}{l}\text { GDP per capita in a country divided by sum of GDPs per capita in all } \\
\text { countries of establishment of multinational firm }\end{array}$ & $\begin{array}{l}\text { Amadeus database (Bureau Van Dijk) and } \\
\text { Ameco database (European Commission) }\end{array}$ \\
\hline $\begin{array}{l}\text { Relative stock market } \\
\text { development }\end{array}$ & $\begin{array}{l}\text { Stock market development, computed as stock market capitalization } \\
\text { relative to GDP, in a country divided by sum of stock market developments } \\
\text { in all countries of establishment of multinational firm }\end{array}$ & $\begin{array}{l}\text { Amadeus database (Bureau Van Dijk) and } \\
\text { Ameco database (European Commission) }\end{array}$ \\
\hline
\end{tabular}

